Published in final edited form as:

Sci Signal. ; 11(515): . doi:10.1126/scisignal.aal2039.

\title{
Fluorescent $\mathrm{Ca}^{2+}$ indicators directly inhibit the $\mathrm{Na}, \mathrm{K}-\mathrm{ATPa}$ a and disrupt cellular functions
}

\author{
Nathan A. Smith ${ }^{1,2}$, Benjamin T. Kress ${ }^{1}$, Yuan Lu ${ }^{1}$, Devin Chandler-Militello ${ }^{1}$, Abdellatif \\ Benraiss $^{1}$, and Maiken Nedergaard ${ }^{1}$ \\ ${ }^{1}$ Center for Translational Neuromedicine, Departments of Neurosurgery and Neurology, University \\ of Rochester Medical Center, Rochester 14642, USA. \\ ${ }^{2}$ Center for Neuroscience Research, Children's Research Institute, Children's National Health \\ System, Washington DC 20010, USA.
}

\begin{abstract}
Fluorescent $\mathrm{Ca}^{2+}$ indicators have been essential for the analysis of $\mathrm{Ca}^{2+}$ signaling events within the cells of the CNS. However, a systematic evaluation of their potential adverse effects is lacking. Here we show that chemical $\mathrm{Ca}^{2+}$ indicators, but not a genetically encoded $\mathrm{Ca}^{2+}$ indicator, potently suppress the activity of $\mathrm{Na}^{+}$- and $\mathrm{K}^{+}$-dependent adenosine triphosphatase (Na,K-ATPase), independently from their $\mathrm{Ca}^{2+}$ chelating activity. Loading of commonly utilized $\mathrm{Ca}^{2+}$ indicators, including Fluo-4 acetoxymethyl (AM), Rhod-2 AM, Fura-2 AM and the $\mathrm{Ca}^{2+}$ chelator BAPTA $\mathrm{AM}$, in cultures of neurons, astrocytes, cardiomyocytes and kidney proximal tubule epithelial cells suppressed $\mathrm{Na}$,KATPase activity by $30-80 \%$. $\mathrm{Ca}^{2+}$ indicators also suppressed agonist-induced activation of Na,K-ATPase, altered metabolic status and produced a dose-dependent loss of cell viability. In vivo, loading of $\mathrm{Ca}^{2+}$ indicators significantly altered brain extracellular concentrations of $\mathrm{K}^{+}$and ATP. A critical review of the previous observations based on chemical $\mathrm{Ca}^{2+}$ indicators is therefore warranted.
\end{abstract}

\section{One sentence summary:}

Fluorescent $\mathrm{Ca}^{2+}$ indicators obstruct Na,K-ATPase and impede cellular metabolism.

\section{INTRODUCTION}

Over the past quarter century, the use of fluorescent $\mathrm{Ca}^{2+}$ indicators has led to a surge of novel insights regarding the dynamics of intracellular $\mathrm{Ca}^{2+}$ signaling(1). As increases in cytosolic $\mathrm{Ca}^{2+}$ represents a primary means of intra- and extracellular signaling, these studies hold potentially far reaching implications affecting many fields of research and applied sciences.

\footnotetext{
Address correspondence to: Maiken Nedergaard, M.D., Ph.D., Center for Translational Neuromedicine, University of Rochester Medical Center, 601 Elmwood Avenue, Box 645, Rochester, NY 14642, nedergaard@ urmc.rochester.edu, Phone: 585-273-2868, Fax: 585-276-2298.

Author contributions: N.A.S., Y.L., and D.C.M. performed the experiments. N.A.S. and Y.L. analyzed data. N.A.S. and M.N. designed the experiments. A.B. provided adenoviruses. N.A.S., B.T.K. and M.N. wrote the paper.

Competing Financial Interests: The authors declare no conflict of interest
} 
Fluorescent $\mathrm{Ca}^{2+}$ indicators were developed based on the principle that the fluorescence spectrum of the $\mathrm{Ca}^{2+}$ selective compound, 1,2-bis(o-aminophenoxy)ethane-N,N,N',N'tetraacetic acid (BAPTA) differs between the $\mathrm{Ca}^{2+}$-free and $\mathrm{Ca}^{2+}$-bound state (2). Multiple $\mathrm{Ca}^{2+}$ indicators have been introduced since Roger Tsien's original publication in 1979, and the impact this discovery has been dramatic. More than 25,700 publications using $\mathrm{Ca}^{2+}$ indicators are listed in PubMed (Supplementary Fig. 1); however, despite widespread use, only sparse evidence exists that details the potential possible side-effects of $\mathrm{Ca}^{2+}$ indicator dyes.

More recently, genetically encoded $\mathrm{Ca}^{2+}$ indicators (GECIs) were developed, including the genetically encoded $\mathrm{Ca}^{2+}$ indicator abbreviated as "GCaMP" (a fusion product of enhanced Green Fluorescence Protein, Calmodulin and the M13 sequence from myosin light chain kinase). After several generations of modifications to increase fluorescence and optimize the signal to noise ratio, GECIs and GCamPs have become widely utilized tools in multiple domains of research $(3,4)$. However, $\mathrm{Ca}^{2+}$ indicator dyes are also still widely utilized (Supplementary Fig. 1) and there is a lack of comparative analysis on how chemical and genetically encoded $\mathrm{Ca}^{2+}$ indicators impact cellular functions.

We have here systematically analyzed the effects of three $\mathrm{Ca}^{2+}$ indicators (Rhod-2, Fluo4 and Fura-2), the $\mathrm{Ca}^{2+}$ chelator, BAPTA, and GCaMP3, on basic cellular functions. As one of the several endpoints, the effects of $\mathrm{Ca}^{2+}$ indicators on the activity of the Na,K-ATPase, a membrane-bound protein, which consumes $\sim 40 \%$ of cellular energy supply $(5,6)$ and is essential for many aspects of cellular membrane functions $(7,8)$ was assessed. We found that all 3 indicators and BAPTA inhibited Na,K-ATPase activity in both intact primary cells and membrane preparations of mouse and human brain astrocytes, mouse heart cardiomyocytes, and human neurons and kidney proximal tubule epithelial cells. Further analysis focused on the characterization of the effects of $\mathrm{Ca}^{2+}$ indicators on cellular functions in the CNS demonstrated that $\mathrm{Ca}^{2+}$ indicators and BAPTA loading also significantly altered neuronal and astrocytic energy metabolism, detected by uptake of $\left[{ }^{3} \mathrm{H}\right]$-2-deoxyglucose $\left(\left[{ }^{3} \mathrm{H}\right]-2-\mathrm{DG}\right)$ and lactate release. Loading of Rhod-2 or Fluo-4 AM in cerebral cortex of awake freely behaving mice induced a marked increase in extracellular $\mathrm{K}^{+}$ and ATP. In contrast, minimal adverse effects of the genetically encoded $\mathrm{Ca}^{2+}$ indicator GCaMP3 were noted. Combined, these observations raise concerns regarding the use of $\mathrm{Ca}^{2+}$ indicator dyes and suggest that genetically encoded $\mathrm{Ca}^{2+}$ indicators interfere less with basic neuronal-glial cell signaling interactions. Our observations, which are focused on analysis of intact brain and cultured neurons and astrocytes, call for a reassessment of prior conclusions based on loading of chemical $\mathrm{Ca}^{2+}$ indicators due to their cytotoxicity and marked effect on basic cellular parameters.

\section{Results}

\section{$\mathrm{Ca}^{2+}$ indicators suppress $\mathrm{Na}, \mathrm{K}-\mathrm{ATPase}-$ mediated ion uptake independent of cell type}

We first assessed the degree to which two of the most commonly used single-wavelength $\mathrm{Ca}^{2+}$ indicators, Fluo- 4 and Rhod-2, as well as the $\mathrm{Ca}^{2+}$ chelator, BAPTA acetoxymethyl ester (AM) (Supplementary Fig. 1), loaded into the cytosol of cultured mouse astrocytes. Fluo-4 AM, Rhod-2 AM, and BAPTA AM were added to the medium in commonly used 
concentrations (Fig. 1a,b and Supplementary Fig. 1). $\mathrm{Ca}^{2+}$ indicator dyes are often chemically-derivatized with an $\mathrm{AM}$, which is $\mathrm{Ca}^{2+}$ insensitive and non-fluorescent, but can readily permeate cellular membrane. The AM ester is then cleaved by endogenous cytosolic esterases, which leads to an accumulation of a cell-impermeable $\mathrm{Ca}^{2+}$ indicator (Fig. 1a) (9). Quantification of the intracellular concentrations of Fluo-4, Rhod-2 and BAPTA showed that all were present in the cytosol in considerably higher concentrations than those added to the medium ( 100 fold) (Fig. 1b). Similarly, the cytosolic concentration of $\mathrm{Ca}^{2+}$ indicator, Quin2, was several hundred times higher than the loading concentration(10).

The effect of the $\mathrm{Ca}^{2+}$ indicators on the Na,K-ATPase was assessed by quantifying ouabainsensitive uptake of a commonly used $\mathrm{K}^{+}$analog, rubidium- $86\left({ }^{86} \mathrm{Rb}^{+}\right)$, in cultured mouse astrocytes $(11,12)$. Both $\mathrm{Ca}^{2+}$ indicators and BAPTA AM effectively suppressed the ouabainsensitive fraction of ${ }^{86} \mathrm{Rb}^{+}$uptake by astrocytes in a dose-dependent manner (Fig. 1c). Of note, application of the solvent, dimethyl sulfoxide (DMSO), did not alter ${ }^{86} \mathrm{Rb}^{+}$ uptake (Supplementary Fig. 2).

We next tested whether the suppression of Na,K-ATPase activity caused by $\mathrm{Ca}^{2+}$ indicators could be observed in different cell types, including cultures of human astrocytes, mouse cardiomyocytes, human renal proximal tubule epithelial cells, and mouse neurons (Fig. 2a-k and Supplementary Movie 1). We also expanded the analysis to other BAPTA-based $\mathrm{Ca}^{2+}$ indicators because of the similarity in their structure (Supplementary Fig. 1d). Fura-2 is the most widely used ratiometric dye (13) (Supplementary Fig. 1a). All cell types analyzed exhibited ouabain-sensitive ${ }^{86} \mathrm{Rb}^{+}$uptake (Fig. 2b,d,f,j). Pretreatment with Fluo-4 AM, Rhod-2 AM, Fura-2 AM or BAPTA AM significantly reduced ${ }^{86} \mathrm{Rb}^{+}$uptake in mouse astrocytes (Fig. 2b). No additional suppression of ${ }^{86} \mathrm{Rb}^{+}$uptake was observed upon coapplication of ouabain (Supplementary Fig. 3), suggesting that $\mathrm{Ca}^{2+}$ indicators have no effect on ouabain-insensitive ${ }^{86} \mathrm{Rb}^{+}$uptake. A striking inhibition of ${ }^{86} \mathrm{Rb}^{+}$uptake by $\mathrm{Ca}^{2+}$ indicators and BAPTA AM was also observed in human astrocytes (Fig. 2d), mouse cardiomyocytes (Fig. 2f), human proximal tubular epithelial cells (Fig. 2h), mouse neurons (Fig. 2j), and rat astrocytes (Supplementary Fig. 5a). Cultured human astrocytes and mouse neurons were most sensitive to loading with $\mathrm{Ca}^{2+}$ indicators and displayed a sharp decrease in ${ }^{86} \mathrm{Rb}^{+}$uptake (Fig. 2d,j).

\section{$\mathrm{Ca}^{2+}$ indicators decrease ATP hydrolysis mediated by $\mathrm{Na}, \mathrm{K}-\mathrm{ATPase}$}

Because the Na,K-ATPase is sensitive to changes in $\mathrm{Ca}^{2+}$ concentrations $(7,14)$, we next tested whether $\mathrm{Ca}^{2+}$ indicators and BAPTA AM reduce the activity of the Na,K-ATPase by altering intracellular $\mathrm{Ca}^{2+}$ concentrations. To control the $\mathrm{Ca}^{2+}$ concentration, we employed a membrane preparation to eliminate cellular control of cytosolic $\mathrm{Ca}^{2+}$. Quantification of ouabain-sensitive ATP hydrolysis was used as an indirect measurement of the Na,K-ATPase activity (15-17). Pre-loading of cultured mouse astrocytes with $\mathrm{Ca}^{2+}$ indicators or BAPTA AM each significantly inhibited the ouabain-sensitive ATP hydrolysis (Fig. 2c). Similarly, human astrocytes (Fig. 2e), mouse cardiomyocytes (Fig. 2g), human proximal tubule epithelial cells (Fig. 2i), mouse neurons (Fig. 2k) and rat astrocytes (Supplementary Fig. 5b) also exhibited suppression of ouabain-sensitive ATP hydrolysis. Thus, observations based on membrane preparations were consistent with the findings in intact cells. However, it is worth 
noting that Fluo-4 AM had no significant effect in kidney cells and cardiomyocytes at $2 \mu \mathrm{M}$, which is within the recommended range $(<5 \mu \mathrm{M})$.

\section{$\mathrm{Ca}^{2+}$ indicators directly suppress $\mathrm{Na}, \mathrm{K}-\mathrm{ATPase}$ activity independently from $\mathrm{Ca}^{2+}$ chelation}

We next sought to evaluate whether the effect of $\mathrm{Ca}^{2+}$ indicators was attributed to AM loading, by using a cell-impermeant form of BAPTA or Rhod-2 (Fig. 3a). Addition of BAPTA $(100 \mu \mathrm{M})$ or Rhod-2 $(10 \mu \mathrm{M})$ inhibited the ouabain-sensitive ATP hydrolysis in membrane preparations derived from cultured mouse or human astrocytes, with a potency that was directly comparable to loading with BAPTA AM or Rhod-2 AM (Fig. 3b,c). This suggests that suppression of the $\mathrm{Na}, \mathrm{K}$-ATPase is a direct effect of the $\mathrm{Ca}^{2+}$ indicators and not a consequence of the preloading of the $\mathrm{AM}$ version of the $\mathrm{Ca}^{2+}$ indicators.

High levels of $\mathrm{Ca}^{2+}$ can inhibit the activity of Na,K-ATPase (7). However, it is unlikely that $\mathrm{Ca}^{2+}$ plays a role in $\mathrm{Ca}^{2+}$ indicator-mediated suppression of the Na,K-ATPase activity, since ouabain-sensitive ATP hydrolysis was inhibited by BAPTA, even in the absence of $\mathrm{Ca}^{2+}$ (Fig. 3d). Moreover, 5,5'-Dibromo BAPTA, which has $\sim 15$-fold lower affinity for $\mathrm{Ca}^{2+}$ than its parent compound BAPTA $(\mathrm{Kd}=1.6 \mu \mathrm{M}$ vs. $110 \mathrm{nM})$, also potently suppressed the $\mathrm{Na}, \mathrm{K}$ ATPase (Fig. 3d).

To further test whether $\mathrm{Ca}^{2+}$ indicators directly affect $\mathrm{Na}$, K-ATPase activity, we next evaluated $\mathrm{Na}$, K-ATPase current in hippocampal pyramidal neurons in the presence and absence of $\mathrm{Ca} 2+$ indicators (Fig. 4a). Using $0.5 \mathrm{mM}$ strophanthidin (18), we were able to directly measure Na, K-ATPase current (Fig. 4b,c). Next, we assessed whether membraneimpermeable Fluo-4, Rhod-2, Fura-2, and BAPTA influence Na, K-ATPase current. Fluo $4(5 \mu \mathrm{M})$, Rhod-2 $(5 \mu \mathrm{M})$, Fura-2 $(5 \mu \mathrm{M})$, and BAPTA $(20 \mu \mathrm{M})$ all significantly inhibited Na, KATPase current in hippocampal pyramidal neurons (Fig. 4d-h). Taken together, these observations suggest that inhibition of the Na,K-ATPase are not attributable to the $\mathrm{Ca}^{2+}$ chelating effects of $\mathrm{Ca}^{2+}$ indicators, but rather to a direct inhibitory effect of the $\mathrm{Ca}^{2+}$ indicators on the $\mathrm{Na}, \mathrm{K}-\mathrm{ATPase}$ or its associated proteins.

\section{$\mathrm{Ca}^{2+}$ indicator loading leads to cell swelling and dose-dependent loss of cell viability}

Blockade of the Na, K-ATPase by ouabain leads to death of cultured rat astrocytes (19). Since $\mathrm{Ca}^{2+}$ indicators inhibited the $\mathrm{Na}$, K-ATPase, we next asked whether $\mathrm{Ca}^{2+}$ indicators also compromise the viability of astrocytes. Cell viability was quantified based on counting of viable cells as well as by of leakage of intracellular constituents (lactate dehydrogenase, LDH). In agreement with previous findings (19), the addition of ouabain for $24 \mathrm{~h}$ decreased the number of viable cells in a dose-dependent manner (Fig. 5a). We next performed this same assessment of cell viability $24 \mathrm{~h}$ after loading of the $\mathrm{Ca}^{2+}$ indicators or BAPTA AM, for either $30 \mathrm{~min}$ or $2 \mathrm{hrs}$, followed by a washing step, to determine if, like ouabain, there was a latent cytotoxic effect of $\mathrm{Ca}^{2+}$ indicators or BAPTA AM loading. Loading of $\mathrm{Ca}^{2+}$ indicators and BAPTA AM for 30 min decreased the viable cell numbers at higher concentrations (Fig. 5a), while a longer loading period ( $2 \mathrm{~h}$ ), which is utilized in many studies (20-24), triggered a sharp decrease in the number of viable cells at $24 \mathrm{~h}$ (Fig. 5b). Because $\mathrm{Ca}^{2+}$ indicators are sometimes dissolved in DMSO, we included a control group that was exposed to just DMSO for $30 \mathrm{~min}$ or $2 \mathrm{~h}$, followed by the same wash-out paradigm 
used for $\mathrm{Ca}^{2+}$ indicators and BAPTA-AM, but observed no reduction in cell viability. In particular, Rhod-2 AM and BAPTA AM were poorly tolerated and the adverse effect was comparable to that of ouabain (Fig. 5a-d). In neuronal cultures, loading of $\mathrm{Ca}^{2+}$ indicators or BAPTA, also had marked cytotoxic effects detected as a significant increase in LDH release (Supplementary Fig. 4).

As an independent assay of inhibition of the Na,K-ATPase, we also assessed cell volume at $24 \mathrm{hrs}$. The Na,K-ATPase, which exports $3 \mathrm{Na}^{+}$ions in exchange for import of $2 \mathrm{~K}^{+}$ions, is an important determinant of cellular volume. The analysis showed that ouabain as expected, as well as the $\mathrm{Ca}^{2+}$ indicators and BAPTA AM, increased cell volume in a dosedependent manner. No effect of DMSO was noted (Fig. 5d; Supplementary Fig. 4).

\section{$\mathrm{Ca}^{2+}$ indicators impair agonist-induced activation of $\mathrm{Na}, \mathrm{K}-\mathrm{ATPase}$}

We previously found that activation of Gq-linked G protein-coupled receptors (GPCRs), including the protease-activated receptor-1 (PAR1)-selective agonist Thr-Phe-Leu-Arg- $\mathrm{NH}_{2}$ (TFLLR-NH ${ }_{2}$ ) can stimulate the astrocytic Na,K-ATPase activity through the production of inositol 1,4,5-triphosphate $\left(\mathrm{IP}_{3}\right)(25)$. In this study, we found that TFLLR-NH ${ }_{2}$-induced increases in ${ }^{86} \mathrm{Rb}^{+}$uptake were suppressed by preloading of BAPTA AM (Fig. 5e). The effect of $\mathrm{Ca}^{2+}$ indicators on the GPCR agonist-induced increase of ${ }^{86} \mathrm{Rb}^{+}$uptake was extended to include astrocyte cultures from transgenic mice expressing an exogenous Gqcoupled receptor (MrgA1) under the control of the inducible human glial fibrillary acidic protein promoter (26). As expected, the MrgA1 agonist peptide, Phe-Met-Arg-Phe amide (FMRF) increased ${ }^{86} \mathrm{Rb}^{+}$uptake, and consistent with our other cell culture results, BAPTA AM-loading inhibited FMRF-induced ${ }^{86} \mathrm{Rb}^{+}$uptake (Fig. 5e). The purinergic agonist, ATP, also enhanced ouabain-sensitive ${ }^{86} \mathrm{Rb}^{+}$uptake in cultured mouse astrocytes (Fig. 5f). Application of Rhod-2 AM and BAPTA AM potently suppressed ATP-induced increases in ${ }^{86} \mathrm{Rb}^{+}$uptake (Fig. 5f). These results extended the finding that $\mathrm{Ca}^{2+}$ indicators inhibit the $\mathrm{Na}, \mathrm{K}$-ATPase activity, by demonstrating that GPCR-mediated stimulation of Na,K-ATPase activity was also disrupted following loading of $\mathrm{Ca}^{2+}$ indicators and BAPTA AM.

\section{$\mathrm{Ca}^{2+}$ indicators alter energy metabolism and $\mathrm{Na}, \mathrm{K}-\mathrm{ATPase}$ activity in vitro and in vivo}

To assess whether $\mathrm{Ca}^{2+}$ indicators also affect cellular energy metabolism, we next quantified $\left[{ }^{3} \mathrm{H}\right]-2-D G$ uptake in cultured mouse astrocytes and neurons (Fig. 6a). Fluo-4 AM, Fura-2 AM, and BAPTA AM all significantly reduced $\left[{ }^{3} \mathrm{H}\right]-2-\mathrm{DG}$ uptake in cultured mouse astrocytes, while Fluo-4 AM and BAPTA AM reduced $\left[{ }^{3} \mathrm{H}\right]-2-\mathrm{DG}$ uptake in cultured mouse neurons. Unexpectedly, however, Rhod-2 AM increased both astrocytic and neuronal $\left[{ }^{3} \mathrm{H}\right]-2-$ DG uptake (Fig. 6b). Rhod-2 is a derivative of Rhodamine 123, known to inhibit the mitochondrial electron transport chain, thereby slowing respiration $(27,28)$ (Fig. 6b). Thus, it is possible that suppression of mitochondrial ATP synthesis enhances glycolysis to fulfill cellular energy demands. In agreement with this hypothesis, Rhod-2 AM-induced an increase in $\left[{ }^{3} \mathrm{H}\right]-2-D G$ uptake that was inhibited by iodoacetate $(300 \mu \mathrm{M})$, an inhibitor of glycolysis (Fig. 6c). Iodoacetate alone decreased $\left[{ }^{3} \mathrm{H}\right]-2-\mathrm{DG}$ uptake, while sodium cyanide $(\mathrm{NaCN}, 100 \mu \mathrm{M})$, an inhibitor of mitochondrial oxidative metabolism (cytochrome c oxidase) enhanced $\left[{ }^{3} \mathrm{H}\right]-2-D G$ uptake in both astrocytes and neurons (Fig. 6c). As an alternative strategy to test whether Rhod-2 AM increases glycolysis, we measured lactate 
production in the same cultures. As expected, both inhibition of oxidative energy metabolism by $\mathrm{NaCN}$ or inhibition of glycolysis by iodoacetate potently controlled lactate production in mouse cultured astrocytes (Fig. 6d). Rhod2 AM loading was also associated with a significant increase in lactate production that was inhibited by co-application of iodoacetate (Fig. 6d). Equally important, we also observed that the Rhod-2 AM loading caused morphological alternations in mitochondria (Fig. 6e), which is supported by a previous study (29). These observations suggest that Rhod-2 AM loading is linked to an increase in glycolysis. By contrast Fluo-4 AM, Fura-2 AM, and BAPTA AM all reduced glucose utilization consistent with the suppression of the Na,K-ATPase activity.

As our in vitro observations raised concern that $\mathrm{Ca}^{2+}$ indicator loading adversely affects cellular functions, we also used microdialysis in freely moving awake mice to evaluate the effect of Rhod-2 and Fluo-4 AM in the intact CNS (Fig. 7a). These experiments are particularly relevant for in vivo two-photon imaging experiments, which frequently employ $\mathrm{Ca}^{2+}$ indicators to analyze cortical $\mathrm{Ca}^{2+}$ dynamics in response to stimulation (30-32). Rhod-2 AM $(5 \mu \mathrm{M})$ was delivered by reverse microdialysis and vibratome sections were prepared immediately after the experiments to confirm conversion of Rhod-2 AM to Rhod-2 based on its fluorescence signal (Fig. 7b). The diameter of tissue with Rhod-2 uptake was $\sim 400 \mu \mathrm{m}$, or comparable to the spatial extent of tissue loading after bolus injection (30). Microdialysates collected before, during and after loading of Rhod-2, Fluo-4 AM or DMSO were used for measurement of extracellular $\mathrm{K}^{+}$concentration, as an indicator of $\mathrm{Na}, \mathrm{K}-$ ATPase activity (Fig. 7c). Compared to DMSO control, Rhod-2 and Fluo-4 AM treatment induced a marked increase in $\mathrm{K}^{+}$concentration that lasted for $45 \mathrm{~min}$ for both (Rhod-2 AM) and (Fluo-4 AM) before gradually returning to baseline levels (Fig. 7C). Interestingly, the extracellular concentration of ATP also increased at 1-2 $\mathrm{h}$ after Rhod-2 or Fluo-4 AM application (Fig. 7d). To examine whether this increase was due to leakage of ATP from dying cells, we evaluated the glycerol concentrations, a marker of cell membrane damage (33). Application of Rhod-2 and Fluo-4 AM did not affect glycerol concentration (Fig. 7d), suggesting that the ATP increase observed after Rhod-2 AM infusion is not a result of cellular damage.

\section{GCaMP expression in astrocytes does not alter $\mathrm{Na}, \mathrm{K}$-ATPase-mediated $\mathrm{K}^{+}$uptake}

Genetically encoded $\mathrm{Ca}^{2+}$ indicators have recently been introduced as alternative tools for analysis of $\mathrm{Ca}^{2+}$ signaling within cells of the CNS (34). To assess whether genetically encoded $\mathrm{Ca}^{2+}$ indicators, also impact basic cellular functions, astrocytes were prepared from double transgenic GFAP-Cre and floxed GCaMP3 mice, in which GCaMP3 is expressed under the control of glial fibrillary acidic protein (GFAP) promoter (GFAP-GCaMP3) (Fig. 8a). Astrocytes expressing GFAP-GCaMP3 showed no difference in basal ouabain-sensitive ${ }^{86} \mathrm{Rb}^{+}$uptake (Fig. 8b). It is, however, possible that the cells have compensated for GCaMP3 expression, because the transgene is expressed during development. To critically assess this possibility, we next prepared cultured astrocytes from GCaMP3fl transgenic mice, and introduced GCaMP3 by transfection with an adenovirus bearing Cre recombinase under cytomegalovirus (CMV) control (AdV-GCaMP3). Astrocytes transfected with AdV-GFP were otherwise prepared as the control cultures. At 6 days post-transduction (100 multiplicities of infection), fluorescence of GCaMP3 and $\mathrm{Ca}^{2+}$ responses to pharmacological 
stimulation by $5 \mu \mathrm{M}$ ATP were confirmed (Supplementary Fig. 6 and Supplementary movies 2-4). Of note, although GFAP-GCaMP3 expression had no effect on ouabain-sensitive ${ }^{86} \mathrm{Rb}^{+}$ uptake, total ${ }^{86} \mathrm{Rb}^{+}$uptake was slightly inhibited in GFAP-GCaMP3-expressing astrocytes (Supplementary Fig. 6e), possibly suggesting that ouabain-insensitive $\mathrm{K}^{+}$uptake via other ion exchangers might be altered. In contrast, in transfected astrocytes, AdV-GCaMP3 expression did not affect either ouabain-sensitive or insensitive ${ }^{86} \mathrm{Rb}^{+}$uptake (Fig. $8 \mathrm{~b}$ and Supplementary Fig. 6e). As expected, Rhod-2 AM loading ( $4 \mu \mathrm{M})$ suppressed ouabainsensitive ${ }^{86} \mathrm{Rb}^{+}$uptake in astrocytes expressing GFAP-GCaMP3, AdV-GCaMP3 or AdVGFP (Fig. 8b). Consistent with previous findings, few spontaneous $\mathrm{Ca}^{2+}$ events were recorded with Rhod-2 and Fluo-4 AM at similar frequency (35). Interestingly, imaging of baseline $\mathrm{Ca}^{2+}$ activity in astrocytes expressing GCaMP3 revealed frequent spontaneous $\mathrm{Ca}^{2+}$ spikes (Fig. 8c). However, after loading with Rhod-2 AM, both GCaMP3 and Rhod-2 channels displayed a low number of $\mathrm{Ca}^{2+}$ events (Fig. 8c). Detection of high frequency $\mathrm{Ca}^{2+}$ oscillations were not due to the improved signal to noise ratio in GCaMP, as $\mathrm{Ca}^{2+}$ indicators have greater signal to noise ratio than GCaMP3. $\mathrm{Ca}^{2+}$ binding to Rhod-2 or Fluo-4 results in an $\sim 100$ fold change in peak emission intensity, whereas GCaMP3 shows $\sim 12$ fold change in peak emission intensity upon $\mathrm{Ca}^{2+}$ binding $(9,36)$. To further test whether Rhod-2 reduced the number of spontaneous $\mathrm{Ca}^{2+}$ events in Adv-GCaMP3 expressing cells by mechanisms other than $\mathrm{Ca}^{2+}$ chelation, we next loaded mouse astrocytes expressing AdvGCaMP3 with 5,5'-Dibromo BAPTA at low concentration (1.6mM). 5,5'-Dibromo BAPTA has a high Kd for $\mathrm{Ca}^{2+}$ binding $(1.6 \mu \mathrm{M})$ thus rendering $\mathrm{Ca}^{2+}$ chelation during physiological conditions negligible. We found that 5,5'-Dibromo BAPTA significantly reduced spontaneous $\mathrm{Ca}^{2+}$ events compared to controls (Fig. 8d). This observation showed a $\mathrm{Ca}^{2+}$ buffer with negligible ability to bind $\mathrm{Ca}^{2+}$ suppressed $\mathrm{Ca}^{2+}$ signaling events in mouse astrocytes, thus suggesting that Rhod-2AM and Fluo-4 AM, at least in part, also may reduce spontaneous $\mathrm{Ca}^{2+}$ signaling by mechanisms other than $\mathrm{Ca}^{2+}$ chelation (Fig. 8c,d and Supplementary Fig. $6)$.

\section{Discussion}

Commercially available $\mathrm{Ca}^{2+}$ indicators have revolutionized our understanding of intracellular $\mathrm{Ca}^{2+}$ signaling over the past three decades (9). Since all the $\mathrm{Ca}^{2+}$ indicators are derivatized from the $\mathrm{Ca}^{2+}$ chelator BAPTA (Supplementary Fig. 1), it is generally acknowledged that they to some extent buffer intracellular $\mathrm{Ca}^{2+}$ and potentially interfere with basic cellular processes $(9,37)$. It was, however, surprising that loading cultured cells with $\mathrm{Ca}^{2+}$ indicators dramatically suppressed the activity of the Na,K-ATPase (Figs. 1-3). Fura-2, Fluo-4, Rhod-2, or BAPTA AM suppressed the Na,K-ATPase activity in five different types of cultured primary cells harvested from brain, heart, and kidney, from either mouse, rat or human (Fig. 2 and Supplementary Fig. 5). Loading of the same $\mathrm{Ca}^{2+}$ indicators or BAPTA AM in the frequently used higher concentrations also resulted in loss of cell viability (Fig. 5 and Supplementary Fig. 1b). Even though the majority of our study was performed on cells from the CNS, the consistency in observations across preparations of different cell types and species suggests the adverse effects of $\mathrm{Ca}^{2+}$ indicators are general and alarming phenomena. In vivo, we found that the $\mathrm{Ca}^{2+}$ indicators caused a transient but marked increase in extracellular $\mathrm{K}^{+}$(from $4 \mathrm{mM}$ up to $10 \mathrm{mM}$ ) following cortical loading of 
Fluo-4 AM or Rhod-2 AM, which was also accompanied by a significant increase in extracellular ATP (Fig. 7). Extracellular $\mathrm{K}^{+}$concentration is a pivotal determinant of membrane potential and is tightly maintained within a range of 3-4 mM (38). Disruption of $\mathrm{K}^{+}$homeostasis is likely to affect neuronal excitability, since even minor increases in extracellular $\mathrm{K}^{+}$concentration will increase neuronal excitability by narrowing the gap between resting membrane potential and the threshold for activation of voltage-gated $\mathrm{Na}^{+}$ channels $(25,39,40)$. Thus, $\mathrm{Ca}^{2+}$ indicators may alter neuronal activity via an inhibition of $\mathrm{K}^{+}$uptake. Importantly, our data suggests that this would occur within time frames used for in vivo imaging of $\mathrm{Ca}^{2+}$ signaling, which typically starts after a $1 \mathrm{~h}$-loading period of $\mathrm{Ca}^{2+}$ indicators (30-32). Toxicity was as expected most pronounced when high loading concentrations were utilized (Fig. 5). This finding is particularly relevant given that a search of the literature showed that high loading concentrations are still utilized (Supplemental Fig. $1)$.

A key question is whether $\mathrm{Ca}^{2+}$ indicators and BAPTA reduce the Na,K-ATPase activity by chelation of cytosolic $\mathrm{Ca}^{2+}$. Prior studies have shown that $\mathrm{Ca}^{2+}$ ions decrease, rather than increase the activity of Na,K-ATPase $(7,14,41)$. Moreover, several observations reported here suggest that cytosolic $\mathrm{Ca}^{2+}$ was not the main driver of the $\mathrm{Ca}^{2+}$ indicator-mediated suppression of the Na,K-ATPase. For example, the potency by which the $\mathrm{Ca}^{2+}$ indicator- and BAPTAinduced inhibition of ouabain-sensitive ${ }^{86} \mathrm{Rb}^{+}$uptake (Rhod-2 AM > Fluo-4 AM > BAPTA AM, Fig. 1c) was not a function of their Kd (BAPTA = Fluo-4 $<$ Rhod-2, Supplementary Fig. 1c). Neither was the rank order of inhibition a function of their intracellular accumulation (BAPTA > Fluo-4 > Rhod-2, Fig. 1b,c). Next, 5,5'-Dibromo BAPTA suppressed the Na,K-ATPase with a potency comparable to BAPTA (Fig. 3d), though its $\mathrm{Ca}^{2+}$ affinity is much lower than BAPTA (Supplementary Fig. 1b). Moreover, a $\mathrm{Ca}^{2+}$ concentration of zero in cell-free ATPase assay buffer exhibited increased Na,KATPase-mediated ATP hydrolysis (Fig. 3d). Finally, GCaMP3 had no effect on ouabainsensitive ${ }^{86} \mathrm{Rb}^{+}$uptake, despite the capacity of GCaMP3 to chelate $\mathrm{Ca}^{2+}$ with a Kd of 345 $\mathrm{nM}$, which is directly comparable to Fluo-4 (Kd=345 nM) (Fig. 8b) (4). An alternative explanation is that the $\mathrm{Ca}^{2+}$ indicators and BAPTA reduced $\mathrm{Na}, \mathrm{K}$-ATPase activity by binding to the Na,K-ATPase directly or interacting with associated proteins. Only $15-35 \%$ of the diffusible $\mathrm{Ca}^{2+}$ indicators are free (unbound state) in the cytosol, while the rest is bound to various cytosolic proteins or trapped in organelles $(42,43)$. The Na,K-ATPase interacts with many membrane and cytosolic proteins including Src and calmodulin to form a protein complex $(14,44,45)$. Powis et al. proposed that calmodulin after binding of $\mathrm{Ca}^{2+}$, constitutes an active complex which is able to stimulate Na,K-ATPase (46). It has been shown that BAPTA directly interacts with several different $\mathrm{Ca}^{2+}$-binding proteins (calmodulin, parvalbumin and trypsin), and that the formation of BAPTA-protein complex occurs regardless whether these proteins are in their $\mathrm{Ca}^{2+}$-free or $\mathrm{Ca}^{2+}$-bound forms (47). The membrane preparations in this study were prepared by hypotonic shock followed by several washes to restore osmolarities. This procedure eliminates most cytoplasmic, but not all membrane-bound proteins (48). Therefore, our analysis cannot define whether $\mathrm{Ca}^{2+}$ indicators and BAPTA reduced pump activity by directly interacting with the Na,K-ATPase or interaction with other membrane-bound modulatory proteins. This limitation is shared by many previous studies and should be subjected to further scrutiny to avoid systematic 
misinterpretation of past results. In addition to the effect of $\mathrm{Ca}^{2+}$ indicators on the $\mathrm{Na}, \mathrm{K}$ ATPase reported here, it has previously been documented that the BAPTA-based $\mathrm{Ca}^{2+}$ chelators, diazo- 2 and dibromo BAPTA, can activate $\mathrm{K}^{+}$channels in rat hippocampal CA1 neurons (49). It is, however, unlikely that formaldehyde generated by hydrolysis of AM form of $\mathrm{Ca}^{2+}$ indicator played an important role in the toxicity observed. For example, the potency of ${ }^{86} \mathrm{Rb}^{+}$uptake inhibition (Rhod-2 AM > Fluo-4 AM > BAPTA AM) does not correlate with the intracellular concentration of the hydrolyzed indicators (BAPTA > Fluo-4 $>$ Rhod-2; Figure 1b), which in a ratio of 1-to-4 reflects the formation of formaldehyde (hydrolysis product) (50). Changes in $\left[{ }^{3} \mathrm{H}\right]-2-\mathrm{DG}$ uptake also do not follow the intracellular concentration of indicators, as those were opposite with Fluo-4 AM and Fura-2 AM (decrease) versus Rhod-2 AM (increase). Furthermore, the salt form of Rhod-2 and BAPTA (without AM) directly inhibited the Na,K-ATPase activity (Figure 3b,c and Figure 4d-h). Thus, the $\mathrm{Ca}^{2+}$ indicator itself rather than formaldehyde produced by AM hydrolysis was the trigger of the deleterious effects on Na,K-ATPase function and metabolic status in our studies. Another important issue is the possible toxicity of the organic solvent DMSO. DMSO is well known for its multiple pharmacological and pathological effects (51). However, our analysis showed that DMSO itself had no significant effect on ${ }^{86} \mathrm{Rb}^{+}$uptake at the concentrations that are typically used in $\mathrm{Ca}^{2+}$ imaging experiments $(0.02-0.2 \%, \mathrm{p}=0.35$, One-way ANOVA, Supplementary Fig. 2). Long-term treatment of DMSO also caused no significant effects on the number of viable cells, LDH release, or cell volume, as shown in Figure 5a-d.

Tsien's group, who also engineered the original $\mathrm{Ca}^{2+}$ indicator dyes, developed the genetically encoded $\mathrm{Ca}^{2+}$ indicator, Cameleon, in which $\mathrm{Ca}^{2+}$-responsive elements such as calmodulin are inserted between two fluorescent proteins (52). Several different types of genetically encoded $\mathrm{Ca}^{2+}$ indicators were subsequently developed, including Camgaroos, Pericams, GCaMPs, and Case (53). To date, GCaMPs are most utilized due to their high fluorescence, rapid kinetics, thermal stability, and the suitable Kd range for measuring cytosolic $\mathrm{Ca}^{2+}$ levels (54). We here show that GCaMP3 did not inhibit the activity of the NaK-ATPase (Fig. 8b). These findings suggest that, GCaMPs or potentially other genetically encoded $\mathrm{Ca}^{2+}$ indicators may be more suitable than chemical $\mathrm{Ca}^{2+}$ indicators for future studies and reassessing previous observations.

In summary, our analysis documents that BAPTA-derived $\mathrm{Ca}^{2+}$ indicators induce a potent inhibition of the Na,K-ATPase activity and suppress spontaneous $\mathrm{Ca}^{2+}$ signaling. By contrast, the genetically encoded $\mathrm{Ca}^{2+}$ indicator GCaMP3 interfered minimally with the $\mathrm{Na}$,KATPase activity. The Na,K-ATPase regulates physiological processes at multiple levels ranging from single cell $\mathrm{Na}^{+}$-coupled glutamate uptake (55) to glucose utilization (56), cell adhesion (57),cellular excitability, and synaptic transmission (25, 58), as well as cardiac (59) and skeletal muscle contraction (60) and blood pressure (61). Given the many roles of the $\mathrm{Na}, \mathrm{K}-\mathrm{ATP}$ ase in physiological and pathological processes, it is imperative to consider the consequences of Na,K-ATPase inhibition in experiments employing $\mathrm{Ca}^{2+}$ indicators or BAPTA. Our study highlights limitations of studies that used $\mathrm{Ca}^{2+}$ indicators in cellular physiology and suggests that a re-evaluation of prior key observations, potentially with genetically encoded $\mathrm{Ca}^{2+}$ indicators, is warranted. 


\section{Materials and Methods}

\section{Cell culture}

Mouse cortical astrocyte cultures were prepared from 0- to 2-day-old C57BL/6 (Charles River Laboratories) mouse pups as previously described (62). For some experiments, we used MrgA $1^{+-}$transgenic and littermate control MrgA $1^{-/}$mice (courtesy of Dr. Ken McCarthy) (26). We also employed the GCaMP3 transgenic mouse, which is based on the flexible Cre/lox system (GCaMP3fl) (Jackson Laboratory). GCaMP3fl mice were crossed with transgenic mice expressing Cre recombinase under the control of GFAP promoter. Astrocytes were prepared from GCaMP3fl and GFAP-Cre:GCaMP3fl double-positive (GFAP-GCaMP3) mice. Briefly, dissociated cells were plated on culture flasks and maintained in DMEM/F12 containing 10\% fetal bovine serum (FBS), 100 units $/ \mathrm{ml}$ penicillin, $100 \mu \mathrm{g} / \mathrm{ml}$ streptomycin, and $25 \mu \mathrm{g} / \mathrm{ml}$ amphotericin B. Astrocytes were subcultured on the plates for subsequent assays.

Mouse neocortical neurons were prepared from 0- to 3-day-old C57BL/6 mouse pups as previously described(63), with slight modification. Briefly, cerebral cortices were dissected and meninges were removed. The tissues were minced and then suspended in Hibernate $\mathrm{A}$ solution minus calcium (BrainBits, LLC) containing papain (Worthington) at $37^{\circ} \mathrm{C}$ for 30 min. The suspension was then triturated with a 9-inch siliconized pipette. The cell suspension was then separated by density gradient centrifugation. The neuronal cells were then seeded onto poly-Dlysine-coated 24-well plates and maintained in Neurobasal A medium (Invitrogen) with $0.5 \mathrm{ml}$ of B27, $0.5 \mathrm{mM}$ GlutaMAX, gentamycin (10 mg ml-1), and human fibroblast growth factor 2 (FGF2) $(5 \mathrm{ng} \mathrm{ml}-1)$ at $37^{\circ} \mathrm{C}$ in an incubator containing humidified air and 5\% $\mathrm{CO}_{2}$. Immunohistochemistry showed that more than $90 \%$ cells in the cultures [identified by DAPI ( $4^{\prime}$,6diamidino- 2-phenylindole)-stained nuclei] were MAP2positive. Neuronal cultures were used 57 days after plating.

Human cortical astrocyte cultures were derived from temporal neocortex as previously described (64) under protocols approved by the University of Rochester-Strong Memorial Hospital Research Subjects Review Board. Briefly the forebrain tissue samples were collected and washed 2-3 times with sterile Hank's balanced salt solution with $\mathrm{Ca}^{++} / \mathrm{Mg}^{++}$ (HBSS+/+). The cortical plate region (CTX) of fetal forebrain was dissected and separated from the ventricular zone/subventricular zone (VZ/SVZ) portion. The CTX was then dissociated with papain as previously described (65). The cells were resuspended at $2-4 \times$ $10^{6}$ cells $/ \mathrm{ml}$ in DMEM/F12 supplemented with N1, $0.5 \%$ PD-FBS and $10 \mathrm{ng} / \mathrm{ml} \mathrm{bFGF}$ and plated in suspension culture dishes. The day after dissociation, cortical cells were recovered and subjected to magnetic activated cell sorting (MACS) for purification of the bipotential glial progenitor cell population (PSA-NCAM-/A2B5 ${ }^{+}$) as previously described (66). The purified GPCs were cultured in DMEM/F12 supplemented with N1 and 5\% FBS to further differentiate them. To prepare culture dishes for ATPase assays or ${ }^{86} \mathrm{Rb}^{+}$uptake measurement, the fetal cortical astrocytes were passaged with papain into single cells and then plated onto poly-L-ornithine/laminin coated 24 well plates (50,000 cells per well).

Mouse cardiomyocyte cultures were prepared from 0- to 2-day-old C57BL/6 mouse pups (Charles River Laboratories) as previously described (67). To prepare the cardiogel matrix 
coated plates, cardiac fibroblasts were obtained from whole hearts of 0- to 5-day-old C57BL/6 mouse pups. The cells were cultured on dishes precoated with $1 \%$ gelatin for 5 days and reseeded onto the plates. When the cultured fibroblasts reached confluency (3-4 days), the extraction buffer ( $0.5 \%$ Triton $\mathrm{X}-100,20 \mathrm{mM} \mathrm{NH}_{4} \mathrm{OH}$ in HBSS) was added to the plate to lyse the cells, and the cellular debris were washed off with chilled HBSS. For the cardiomyocyte, the heart ventricles were excised, and the auricles were carefully removed and discarded. The cardiomyocytes were dispersed by incubating with $0.5 \%$ trypsin-EDTA $\left(4 \times 5 \mathrm{~min}, 37^{\circ} \mathrm{C}\right)$ and purified by the differential attachment of nonmyocardial cells to the $1 \%$ gelatin-precoated dishes $(2 \times 1.5 \mathrm{~h})$. The nonadhesive cells (cardiomyocytes) were transferred into the cardiogel matrix coated plates and cultured in the DMEM/F12 media supplemented with $20 \% \mathrm{FBS}, 5 \%$ horse serum, $2 \mathrm{mM}$ glutamine, $0.1 \mathrm{mM}$ nonessential amino acids, $3 \mathrm{mM}$ sodium pyruvate, $1 \mu \mathrm{g} / \mathrm{ml}$ bovine insulin, $100 \mathrm{units} / \mathrm{ml}$ penicillin, 100 $\mu \mathrm{g} / \mathrm{ml}$ streptomycin, $25 \mu \mathrm{g} / \mathrm{ml}$ amphotericin B. Beating cardiomyocytes were clearly observed on third day in culture (Supplementary Movie 1).

Human renal proximal tubule epithelial cells were obtained from Lifeline Cell Technology (Frederick) and cultured according to the manufacture's protocol with the RenaLife basal medium containing $0.5 \%$ FBS, $5 \mu \mathrm{g} / \mathrm{ml}$ recombinant human insulin, $0.1 \mu \mathrm{g} / \mathrm{ml}$ hydrocortisone hemisuccinate, $2.4 \mathrm{mM}$ L-analyl-L-glutamate, $1 \mu \mathrm{M}$ epinephrine, $5 \mu \mathrm{g} / \mathrm{ml}$ transferring, $10 \mathrm{nM}$ triiodothyronine, $10 \mathrm{ng} / \mathrm{ml}$ recombinant human EGF, 100 units $/ \mathrm{ml}$ penicillin, $100 \mu \mathrm{g} / \mathrm{ml}$ streptomycin, and $25 \mu \mathrm{g} / \mathrm{ml}$ amphotericin B. All culture cells were incubated in the condition of $5 \% \mathrm{CO}_{2} / 95 \%$ air at $37^{\circ} \mathrm{C}$. All animal procedures were approved by the institutional Animal Care and Use Committee of University of Rochester.

\section{Titration of adenoviral infection of GCaMP3fl astrocytes}

To induce GCaMP3 expression in cortical mouse astrocyte cultures prepared from GCaMP3fl mice, cells were infected with adenovirus bearing Cre recombinase under the control of the constitutive cytomegalovirus (CMV) promoter (courtesy of Aris N. Economides from Regeneron Pharmaceuticals, Tarrytown, NY) for $5 \mathrm{~h}$ with 10, 50 or 100 multiplicities of infection (MOI). At day 6 after transduction, GCaMP3 expression was confirmed under the microscope and cells were used for $\mathrm{Ca}^{2+}$ imaging and ${ }^{86} \mathrm{Rb}^{+}$uptake experiments (AdV-GCaMP3). Cytotoxicity was not observed with 10-100 MOI. For control experiments, cells were infected with adenovirus bearing green fluorescent protein (GFP) under the control of CMV promoter (AdV-GFP control) (68).

\section{$\mathrm{Ca}^{2+}$ imaging}

$\mathrm{Ca}^{2+}$ imaging methods were identical to those described previously (25). Astrocytes without or with GCaMP3 expression (GFAP-GCaMP3 and AdV-GCaMP3) expression were loaded with Fluo-4 AM (2 or $4 \mu \mathrm{M})$, Rhod-2 AM (2.25 or $4.5 \mu \mathrm{M})$, or DMSO $(0.1 \%)$ for $30 \mathrm{~min}$ at $37^{\circ} \mathrm{C}$ followed by washing with DMEM/F12 media for the intracellular $\mathrm{Ca}^{2+}$ imaging. AM indicators were initially dissolved in DMSO then introduced to culture media. Images were taken using a confocal microscope (FV500, Olympus) at $1.2 \mathrm{~s}$ per frame with $488 \mathrm{~nm}$ laser for GCaMP and Fluo-4 or $532 \mathrm{~nm}$ laser for Rhod-2. Cells were kept at $37^{\circ} \mathrm{C}$ with a stage heater during the imaging. For stimulation with $5 \mu \mathrm{M}$ ATP, 15 visually identifiable cell bodies were randomly selected in each image. Circular regions of interest (ROIs) were used 
and the fluorescence time course of each cell was measured by averaging all pixels within the ROI. Frequency of spontaneous $\mathrm{Ca}^{2+}$ events was obtained by counting the total numbers of $\mathrm{Ca}^{2+}$ events for a period of $5 \mathrm{~min}$ in a field spanning $1273 \mu \mathrm{m} \times 1273 \mu \mathrm{m}$ of each image.

\section{${ }^{86} \mathrm{Rb}^{+}$uptake measurement}

${ }^{86} \mathrm{Rb}^{+}$uptake measurement was conducted as previously described with a slight modification (25). We used dimethyl sulfoxide (DMSO) to initially dissolve membrane permeable AM-linked $\mathrm{Ca}^{2+}$ indicators, and therefore, DMSO was used as a vehicle control for experiments. In each set of experiments, all groups received the same amount of DMSO, except in Supplementary Fig. 2, in which the effect of DMSO was examined. Cells were loaded with various concentrations of Fluo-4 AM $(0-10 \mu \mathrm{M})$, Rhod-2 AM $(0-10 \mu \mathrm{M})$, Fura-2 AM $(0-8 \mu \mathrm{M})$, BAPTA AM $(0-40 \mu \mathrm{M})$ or identical amount of DMSO $(0-0.2 \%)$ for $20 \mathrm{~min}$ and further incubated in the presence or absence of ouabain $(1 \mathrm{mM})$ for $10 \mathrm{~min}$ (30 min total incubation with $\mathrm{AM}$ indicators at $\left.37^{\circ} \mathrm{C}\right)$. The potassium analogue ${ }^{86} \mathrm{Rb}^{+}$was added to each well for $15 \mathrm{~min}\left(1 \mu \mathrm{Ci}\right.$, Perkin Elmer), and the ${ }^{86} \mathrm{Rb}^{+}$uptake was quantified by liquid scintillation counting (Beckman Coulter). Data were normalized to cell numbers for comparison of cultures prepared from different transgenic mice. Ouabain-sensitive ${ }^{86} \mathrm{Rb}^{+}$ uptake was calculated by subtracting ${ }^{86} \mathrm{Rb}^{+}$uptake during the same conditions, but in the presence of ouabain.

\section{[ $\left.{ }^{3} \mathrm{H}\right]$-2-deoxyglucose $\left(\left[{ }^{3} \mathrm{H}\right]-2-D G\right)$ uptake and lactate release measurement}

Glucose uptake was determined by using 2-deoxyglucose labeled with tritium (69). Cells were loaded with various concentrations of $\mathrm{Ca}^{2+}$ indicators, BAPTA AM or identical amount of DMSO as described in ${ }^{86} \mathrm{Rb}^{+}$uptake measurement section in the presence or absence of iodoacetate $(300 \mu \mathrm{M})$ and sodium cyanide $(100 \mu \mathrm{M})$. The supernatants $(100 \mu \mathrm{l})$ were collected for lactate release measurement after a $30 \mathrm{~min}$ incubation period at $37^{\circ} \mathrm{C}$, followed by the addition of the glucose analogue $\left[{ }^{3} \mathrm{H}\right]-2-\mathrm{DG}$ to each well and incubation for $15 \mathrm{~min}(1$ $\mu \mathrm{Ci}$, Perkin Elmer). $\left[{ }^{3} \mathrm{H}\right]-2 \mathrm{DG}$ uptake and lactate release can therefore not directly be compared. $\left[{ }^{3} \mathrm{H}\right]-2-D G$ uptake was quantified by liquid scintillation counting (Beckman Coulter). $\left[{ }^{3} \mathrm{H}\right]-2-D G$ uptake was expressed as percentage of control $\left[{ }^{3} \mathrm{H}\right]-2-D G$ uptake. The concentrations of lactate in samples were measured by using lactate assay kit (Abcam Inc.).

\section{Neuronal Lactate release measurement}

Cells were incubated with ouabain $(1 \mathrm{mM}), \mathrm{Ca}^{2+}$ indicators ( $2-5 \mu \mathrm{M}$ in $\left.0.2 \% \mathrm{DMSO}\right)$, or BAPTA AM (5-10 $\mu \mathrm{M}$ in $0.2 \%$ DMSO) for 30 minutes at $37^{\circ} \mathrm{C}$, then washed 4 times. The supernatant was collected 6 and 24 hours after incubation. The concentrations of lactate were measured by using LDH Colorimetric Assay Kit (Abcam Inc.).

\section{ATPase assay}

The Na,K-ATPase-mediated ATP hydrolysis was measured as reported earlier with a slight modification $(15,17,70)$. After the loading of $\mathrm{Ca}^{2+}$ indicators, BAPTA AM or DMSO, as described in ${ }^{86} \mathrm{Rb}^{+}$uptake measurement, the cells were washed 5 times with Tris-buffered water $(15 \mathrm{mM}$ Tris- $\mathrm{HCl}, \mathrm{pH} 7.4)$ and lysed for $4-12 \mathrm{~h}$ at $4^{\circ} \mathrm{C}$. The cell ghosts were carefully washed and collected from the culture plate by using cell lifter (Corning) in assay buffer 
containing $100 \mathrm{mM} \mathrm{NaCl}, 15 \mathrm{mM} \mathrm{KCl}, 5 \mathrm{mM} \mathrm{MgCl} 2,500 \mathrm{nM} \mathrm{CaCl}_{2}, 50 \mathrm{mM}$ Tris and protease inhibitor cocktail $(100 \times), \mathrm{pH} 7.4 . \mathrm{Ca}^{2+}$ concentration in the assay buffer was modified ( 0 or $500 \mathrm{nM}$ ) where indicated. The collected cell ghosts were divided into 2 groups and used for ATP hydrolysis and protein measurement. In ATP hydrolysis measurement, the membrane preparation was preincubated for $10 \mathrm{~min}$ at $37^{\circ} \mathrm{C}$. For some experiments, Rhod-2 tripotassium salt $(10 \mu \mathrm{M})$, BAPTA tetrapotassium salt $(100 \mu \mathrm{M})$, or 5,5'-Dibromo BAPTA tetrapotassium salt $(100 \mu \mathrm{M})$ were added to membrane preparation. Vanadate-free ATP $(1 \mathrm{mM})$ was used as the substrate $(71,72)$, and the liberated inorganic phosphate during $10 \mathrm{~min}$ incubation at $37^{\circ} \mathrm{C}$ in the presence or absence of ouabain $(1 \mathrm{mM})$ was quantified by using malachite green phosphate detection kit (R\&D Systems). Ouabainsensitive ATPase activity was calculated and expressed as nanomoles of inorganic phosphate released per mg protein per min. The protein concentration in the samples was measured by BCA protein assay (Pierce).

\section{Intracellular Fluo-4, Rhod-2 and BAPTA concentration measurements}

After the incubation period with Fluo-4 AM, Rhod-2 AM, BAPTA AM or DMSO, cells were gently washed 4 times with assay buffer, then collected in assay buffer by using cell lifter. For Fluo-4 and Rhod-2 samples collection, we used the assay buffer supplemented with $100 \mu \mathrm{M} \mathrm{Ca}^{2+}$ to maximize the fluorescent intensity. For BAPTA sample collection, we used the assay buffer without $\mathrm{CaCl}_{2}$ and supplemented with $1 \mathrm{mM}$ EGTA to maximize the optical density. In pilot studies, we confirmed that EGTA itself $(1 \mathrm{mM})$ doesn't show the detectable absorption at $260 \mathrm{~nm}$ but effectively maximized the absorption of BAPTA by replacing the $\mathrm{Ca}^{2+}$ binding. Cells were dissolved by sonication and centrifuged at 12,000 rpm for $5 \mathrm{~min}$. The supernatant was used for measurement. The fluorescence readings (Fluo-4, excitation $485 \mathrm{~nm}$ and emission $535 \mathrm{~nm}$; Rhod-2, excitation $530 \mathrm{~nm}$ and emission $620 \mathrm{~nm}$ ) were performed using a luminometer (PerkinElmer, Victor2, Wallac), and the absorption at $260 \mathrm{~nm}$ was detected by using a spectrophotometer (Molecular Devices, SpectraMax). The standards were generated from DMSO-treated control cells with identical procedure written above and supplemented with various concentrations of Fluo-4 (10-1000 $\mathrm{nM})$, Rhod-2 (10-1000 nM) or BAPTA $(0.5-32 \mu \mathrm{M})$ salts. The intracellular concentrations were calculated from total cell number and cell volume measured by using Scepter ${ }^{\text {TM }} 2.0$ cell counter (EMD Millipore Corp.).

\section{Lactate dehydrogenase (LDH) assay}

$\mathrm{LDH}$ released into the media was measured as a marker of dead cells. Various concentrations of ouabain ( $0-5 \mathrm{mM}), \mathrm{Ca}^{2+}$ indicators (1-10 $\mu \mathrm{M}$ in $0.2 \%$ DMSO), BAPTA AM (5-40 $\mu \mathrm{M}$ in $0.2 \%$ DMSO) or DMSO $(0.02-0.2 \%)$ were incubated with cells for $2 \mathrm{~h}$ at $37^{\circ} \mathrm{C}$, and the culture supernatant was collected for LDH assay. The concentrations of LDH in the samples were detected by using LDH cytotoxicity assay kit II (Abcam Inc.).

\section{Cell volume and viability assessment}

For the viable cell counting, we used the Scepter ${ }^{\mathrm{TM}} 2.0$ cell counter to rapidly count the cell numbers and diameters. The cells were incubated with ouabain $(0-5 \mathrm{mM}), \mathrm{Ca}^{2+}$ indicators (1-10 $\mu \mathrm{M}$ in $0.2 \%$ DMSO), BAPTA AM (5-40 $\mu \mathrm{M}$ in 0.2\% DMSO) or DMSO (0.02-0.2\%) for $30 \mathrm{~min}$ or $2 \mathrm{~h}$ at $37^{\circ} \mathrm{C}$. After washing with serum-free media at $30 \mathrm{~min}$ or $2 \mathrm{~h}$, the cells 
were further incubated for a total period of $24 \mathrm{~h}$ and directly sampled from the plate into the tip attached to the cell counter. A debris/dead cell fraction appeared in the smaller diameter range ( $>11 \mu \mathrm{m})$, and it was excluded from the viable cell number. In Supplemental Figure 4, cells were washed 4 times in PBS and centrifuged. The cells were then resuspended in various concentrations of $\mathrm{Ca}^{2+}$ indicator buffers and incubated for 30 minutes at room temperature. The samples were analyzed using ImageStream.(73)

\section{In vivo microdialysis and measurement of $\mathrm{K}^{+}, \mathrm{ATP}$, and glycerol}

The effects of Rhod-2 and Fluo-4 AM loading in the intact brain were evaluated by using microdialysis in freely moving awake mice. This approach permits the changes before, during and after loading of Rhod-2 and Fluo-4 AM to be directly monitored by collection of interstitial fluid. For surgical implantation of microdialysis guide cannula, 8- to 12-week-old C57BL/6 mice (Charles River) were anesthetized with a mixture of ketamine $(60 \mathrm{mg} / \mathrm{kg}$, i.p.) and xylazine $(10 \mathrm{mg} / \mathrm{kg}$, i.p.). The guide cannula was stereotactically implanted in somatosensory cortex as previously described (74). Following surgery, animals were given a recovery period ( $24 \mathrm{~h}$ ). Microdialysis probes ( $2 \mathrm{~mm}$ membrane length, $30 \mathrm{kDa}$ cut-off, BASi) were carefully inserted, and the probe tip was positioned at the following coordinate: anterior-posterior, $-1.5 \mathrm{~mm}$; mediallateral, $+3.96 \mathrm{~mm}$ (probe angle $35^{\circ}$ ); dorsal-ventral, -2.0 $\mathrm{mm}$ (probe angle $45^{\circ}$ ). Following the overnight equilibration with artificial cerebrospinal fluid (aCSF, in mM: $\mathrm{NaCl} 145, \mathrm{KCl} 4, \mathrm{CaCl}_{2} 1, \mathrm{MgCl}_{2} 1, \mathrm{NaH}_{2} \mathrm{PO}_{4} 1.25$, HEPES 15, $\mathrm{pH}$ 7.4), the microdialysates were collected every $15 \mathrm{~min}$ (flow rate at $2 \mu \mathrm{l} / \mathrm{min}$ ). Rhod-2 and Fluo-4 AM $(5 \mu \mathrm{M})$ were prepared in $0.1 \%$ Pluronic F-127, 0.1\% DMSO and aCSF and filtered with $0.2 \mu \mathrm{m}$ pore syringe filters (Nalge Nunc International). In two-photon imaging experiments, $\mathrm{Ca}^{2+}$ indicators are usually loaded into tissue with multicell bolus loading or surface application. For multicell bolus loading, high concentrations but small volume of $\mathrm{Ca}^{2+}$ indicators are pressure-ejected intracortically from the micropipette positioned at 150 $750 \mu \mathrm{m}$ below the pia (0.4-1.0 fmol, approximately) followed by a $1-1.5 \mathrm{~h}$ waiting period $(30,31,75)$. For surface application, which was also used in our earlier studies $(74,76), 18$ $45 \mathrm{nmol}$ of $\mathrm{Ca}^{2+}$ indicators are generally applied onto the exposed surface of cortical tissue and incubated for 45-60 min to stain astrocytes in the superficial layer $(32,75,77)$. In the present study, we delivered 20-38 pmol of $\mathrm{Ca}^{2+}$ indicator into cortex for a period of $1 \mathrm{~h}$. The aCSF containing Pluronic F-127 and DMSO was used as control. The collected samples were divided into 2 aliquots, $12 \mu \mathrm{l}$ for ATP and glycerol measurement and $18 \mu \mathrm{l}$ for $\mathrm{K}^{+}$ measurement, and were immediately stored at $-80^{\circ} \mathrm{C}$.

To measure $\mathrm{K}^{+}$changes in the microdialysates, the ion-sensitive microelectrodes were made as previously described $(25,78)$. Briefly, Pipettes were silanized by dimethyldichlorosilane (Silanization Solution I, Sigma) and loaded with a 100-150 $\mu \mathrm{m}$ column of $\mathrm{K}^{+}$exchanger (potassium ionophore I-cocktail B, Sigma). The electrodes were calibrated prior to experiments with 2-20 $\mathrm{mM} \mathrm{K}^{+}$in aCSF and were recalibrated at the end of each experiment. Baseline was monitored by randomly running standard during measurement of samples. The ATP concentrations in the microdialysates were measured by using a bioluminescent ATP assay mix (Sigma) and a Victor 2 plate reader (Wallac). The concentration of glycerol in the samples were detected by using free glycerol detection kit, glucose assay kit, lactate assay kit (Abcam Inc.), respectively, following manufacture's instructions. 


\section{Recording of $\mathrm{Na}^{+}-\mathrm{K}^{+}-$ATPase current on hippocampal slice.}

Coronal hippocampal brain slices $(300 \mu \mathrm{m})$ were prepared from 8-12 week old mice.

Briefly, hippocampal slices were cut using a Leica VT1000s (Leica Biosystems, Buffalo Grove, IL) in ice-cold slicing buffer (in mM: $127 \mathrm{NaCl}, 26 \mathrm{NaHCO}_{3}, 1.2 \mathrm{KH}_{2} \mathrm{PO}_{4}, 1.9 \mathrm{KCl}$, $1.1 \mathrm{CaCl}_{2}, 2 \mathrm{MgSO}_{4}, 10 \mathrm{D}$-Glucose) bubbled with $95 \% \mathrm{O}_{2}$ and $5 \% \mathrm{CO}_{2}$. Slices were then transferred to a holding chamber containing oxygenated artificial cerebrospinal fluid (ACSF; in mM: $127 \mathrm{NaCl}, 26 \mathrm{NaHCO}_{3}, 1.2 \mathrm{KH}_{2} \mathrm{PO}_{4}, 1.9 \mathrm{KCl}, 2.2 \mathrm{CaCl}_{2}, 1 \mathrm{MgSO}_{4}, 10$ D-Glucose) for $30 \mathrm{~min}$ at $34^{\circ} \mathrm{C}$ and for another $30 \mathrm{~min}$ at room temperature for recovery, and then transferred to a submersion recording chamber continually perfused with oxygenated ACSF containing $1 \mu \mathrm{M}$ tetrodotoxin (TTX, Sigma) at room temperature (rate: $2 \mathrm{ml} / \mathrm{min}$ ). Slices were equilibrated for at least 15 min before each recording.

Whole-cell recordings from pyramidal neurons in hippocampal CA1 region were made using a Multiclamp 700B amplifier (Axon Instruments, Foster City, CA), sampled at 10 $\mathrm{kHz}$, digitized by a DigiData 1440A, and later analyzed off-line by ClampFit (Axon software). Recording pipettes with resistances ranging between 3-6 MW were pulled using standard borosilicate capillaries by a two-step electrode puller (PC-10, Narishige, Amityville, NY) and were filled with a K-gluconate based patch solution (in mM: $125 \mathrm{~K}$ Gluconate, $20 \mathrm{KCl}, 10 \mathrm{NaCl}, 2 \mathrm{Mg}$-ATP, $0.3 \mathrm{Na}$-GTP, 2.5 QX314, 10 HEPES, pH 7.3 adjusted with $\mathrm{KOH}$ ). As $\mathrm{Na}^{+}-\mathrm{K}^{+}$-ATPase is constantly moving $3 \mathrm{Na}^{+}$ions out of the cell and $2 \mathrm{~K}^{+}$ions into the cell, the pump generates a constant outward current. By inhibiting this constant outward current with strophanthidin $(0.5 \mathrm{mM}$, Sigma), the holding current is decreased and such inward move of the holding current recorded at $-70 \mathrm{mV}$ is measured as the current carried by $\mathrm{Na}^{+}-\mathrm{K}^{+}$-ATPase. Membrane impermeable calcium indicators were added into patch solution to test their effect on the current carried by $\mathrm{Na}^{+}-\mathrm{K}^{+}$-ATPase.

\section{Statistics}

Values are expressed as means \pm S.E.M. All data represent four or more independent experiments, and in vitro results were obtained from separate cultures. Normality of the data was evaluated with Shapiro-Wilk test with a $=0.05$. Differences between two means were assessed by Student's $t$ test, and differences among multiple means were assessed by oneway analysis of variance (ANOVA) with Tukey-Kramer post hoc test or two-way ANOVA with Bonferroni post hoc test. The null hypothesis was rejected when $\mathrm{p}$ value is less than 0.05 .

\section{Supplementary Material}

Refer to Web version on PubMed Central for supplementary material.

\section{Acknowledgments:}

\footnotetext{
We thank Vittorio Gallo for valuable comments on the manuscript. We thank Dr. Ken McCarthy for generously sharing transgenic mice.

Funding: This work was supported by National Institutes of Health grants (NS078167 and NS078304 to M.N.) and F31 National Research Service Award and T32 Post Doctoral (F31NS073390 and 5T32D046388-09 to N.A.S.).
} 


\section{References}

1. Clapham DE, Calcium signaling. Cell 131, 1047-1058 (2007). [PubMed: 18083096]

2. Tsien RY, New calcium indicators and buffers with high selectivity against magnesium and protons: design, synthesis, and properties of prototype structures. Biochemistry 19, 2396-2404 (1980). [PubMed: 6770893]

3. Zariwala HA, Borghuis BG, Hoogland TM, Madisen L, Tian L, De Zeeuw CI, Zeng H, Looger LL, Svoboda K, Chen TW, A Cre-dependent GCaMP3 reporter mouse for neuronal imaging in vivo. The Journal of neuroscience : the official journal of the Society for Neuroscience 32, 3131-3141 (2012). [PubMed: 22378886]

4. Chen TW, Wardill TJ, Sun Y, Pulver SR, Renninger SL, Baohan A, Schreiter ER, Kerr RA, Orger MB, Jayaraman V, Looger LL, Svoboda K, Kim DS, Ultrasensitive fluorescent proteins for imaging neuronal activity. Nature 499, 295-300 (2013). [PubMed: 23868258]

5. Milligan LP, McBride BW, Energy costs of ion pumping by animal tissues. J Nutr 115, 1374-1382 (1985). [PubMed: 2413191]

6. Ames A, 3rd, CNS energy metabolism as related to function. Brain Res Brain Res Rev 34, 42-68 (2000). [PubMed: 11086186]

7. Skou JC, The influence of some cations on an adenosine triphosphatase from peripheral nerves. Biochim Biophys Acta 23, 394-401 (1957). [PubMed: 13412736]

8. Hoffman JF, Cation transport and structure of the red-cell plasma membrane. Circulation 26, 12021213 (1962). [PubMed: 13963929]

9. Takahashi A, Camacho P, Lechleiter JD, Herman B, Measurement of intracellular calcium. Physiol Rev 79, 1089-1125 (1999). [PubMed: 10508230]

10. Tsien RY, Pozzan T, Rink TJ, Calcium homeostasis in intact lymphocytes: cytoplasmic free calcium monitored with a new, intracellularly trapped fluorescent indicator. J Cell Biol 94, 325334 (1982). [PubMed: 6980885]

11. Noguchi S, Mishina M, Kawamura M, Numa S, Expression of functional (Na++ K+)ATPase from cloned cDNAs. FEBS Lett 225, 27-32 (1987). [PubMed: 2826244]

12. Herrera VL, Ruiz-Opazo N, Alteration of alpha $1 \mathrm{Na}+, \mathrm{K}(+)$-ATase $86 \mathrm{Rb}+$ influx by a single amino acid substitution. Science 249, 1023-1026 (1990). [PubMed: 1975705]

13. Tsien RY, Rink TJ, Poenie M, Measurement of cytosolic free $\mathrm{Ca} 2+$ in individual small cells using fluorescence microscopy with dual excitation wavelengths. Cell calcium 6, 145-157 (1985). [PubMed: 3874696]

14. Yingst DR, Modulation of the Na,K-ATPase by Ca and intracellular proteins. Annu Rev Physiol 50, 291-303 (1988). [PubMed: 2837135]

15. Bonting SL, Simon KA, Hawkins NM, Studies on sodium-potassium-activated adenosine triphosphatase. I. Quantitative distribution in several tissues of the cat. Arch Biochem Biophys 95, 416-423 (1961). [PubMed: 13871109]

16. Hanahan DJ, Ekholm JE, The preparation of red cell ghosts (membranes). Methods Enzymol 31, 168-172 (1974). [PubMed: 4278921]

17. Morth JP, Pedersen BP, Toustrup-Jensen MS, Sorensen TL, Petersen J, Andersen JP, Vilsen B, Nissen P, Crystal structure of the sodium-potassium pump. Nature 450, 1043-1049 (2007). [PubMed: 18075585]

18. Zhang LN, Su SW, Guo F, Guo HC, Shi XL, Li WY, Liu X, Wang YL, Serotonin-mediated modulation of $\mathrm{Na}+\mathrm{K}+$ pump current in rat hippocampal $\mathrm{CA} 1$ pyramidal neurons. BMC Neurosci 13, 10 (2012). [PubMed: 22257758]

19. Sontheimer H, Fernandez-Marques E, Ullrich N, Pappas CA, Waxman SG, Astrocyte Na+ channels are required for maintenance of $\mathrm{Na}+/ \mathrm{K}(+)$-ATPase activity. The Journal of neuroscience : the official journal of the Society for Neuroscience 14, 24642475 (1994).

20. Linan-Rico A, Wunderlich JE, Enneking JT, Tso DR, Grants I, Williams KC, Otey A, Michel K, Schemann M, Needleman B, Harzman A, Christofi FL, Neuropharmacology of purinergic receptors in human submucous plexus: Involvement of P2X P2X, P2X channels, P2Y and A metabotropic receptors in neurotransmission. Neuropharmacology 95, 83-99 (2015). [PubMed: 25724083] 
21. Weber JF, Waldman SD, Calcium signaling as a novel method to optimize the biosynthetic response of chondrocytes to dynamic mechanical loading. Biomech Model Mechanobiol 13, 1387-1397 (2014). [PubMed: 24696123]

22. Woehrling EK, Parri HR, Tse EH, Hill EJ, Maidment ID, Fox GC, Coleman MD, A predictive in vitro model of the impact of drugs with anticholinergic properties on human neuronal and astrocytic systems. PLoS One 10, e0118786 (2015). [PubMed: 25738989]

23. Smith IF, Boyle JP, Plant LD, Pearson HA, Peers C, Hypoxic remodeling of Ca2+ stores in type I cortical astrocytes. J Biol Chem 278, 4875-4881 (2003). [PubMed: 12477727]

24. Murphy TH, Blatter LA, Wier WG, Baraban JM, Spontaneous synchronous synaptic calcium transients in cultured cortical neurons. The Journal of neuroscience : the official journal of the Society for Neuroscience 12, 4834-4845 (1992). [PubMed: 1361198]

25. Zhou Y, Guo LX, Yu DN, Zhou L, Wang Y, Mou ZQ, Wang XX, Zhang LN, Li M, [Analyses on the relative factors regarding diabetic nephropathy among 1758 cases of type 2 diabetic patients]. Zhonghua Liu Xing Bing Xue Za Zhi 33, 610-613 (2012). [PubMed: 22883271]

26. Fiacco TA, Agulhon C, Taves SR, Petravicz J, Casper KB, Dong X, Chen J, McCarthy KD, Selective stimulation of astrocyte calcium in situ does not affect neuronal excitatory synaptic activity. Neuron 54, 611-626 (2007). [PubMed: 17521573]

27. Zigman S, Gilman P, Jr., Inhibition of cell division and growth by a redox series of cyanine dyes. Science 208, 188-191 (1980). [PubMed: 7361115]

28. Modica-Napolitano JS, Weiss MJ, Chen LB, Aprille JR, Rhodamine 123 inhibits bioenergetic function in isolated rat liver mitochondria. Biochem Biophys Res Commun 118, 717-723 (1984). [PubMed: 6200108]

29. Fonteriz RI, de la Fuente S, Moreno A, Lobaton CD, Montero M, Alvarez J, Monitoring mitochondrial $[\mathrm{Ca}(2+)]$ dynamics with rhod-2, ratiometric pericam and aequorin. Cell calcium 48 , 61-69 (2010). [PubMed: 20667591]

30. Stosiek C, Garaschuk O, Holthoff K, Konnerth A, In vivo two-photon calcium imaging of neuronal networks. Proc Natl Acad Sci U S A 100, 7319-7324 (2003). [PubMed: 12777621]

31. Garaschuk O, Milos RI, Konnerth A, Targeted bulk-loading of fluorescent indicators for twophoton brain imaging in vivo. Nat Protoc 1, 380-386 (2006). [PubMed: 17406260]

32. Hirase H, Qian L, Bartho P, Buzsaki G, Calcium dynamics of cortical astrocytic networks in vivo. PLoS Biol 2, E96 (2004). [PubMed: 15094801]

33. Goodman JC, Robertson CS, Microdialysis: is it ready for prime time? Curr Opin Crit Care 15, 110-117 (2009). [PubMed: 19578321]

34. Tian L, Hires SA, Looger LL, Imaging neuronal activity with genetically encoded calcium indicators. Cold Spring Harb Protoc 2012, 647-656 (2012). [PubMed: 22661439]

35. Parri HR, Crunelli V, The role of $\mathrm{Ca} 2+$ in the generation of spontaneous astrocytic $\mathrm{Ca} 2+$ oscillations. Neuroscience 120, 979-992 (2003). [PubMed: 12927204]

36. Akerboom J, Chen TW, Wardill TJ, Tian L, Marvin JS, Mutlu S, Calderon NC, Esposti F, Borghuis BG, Sun XR, Gordus A, Orger MB, Portugues R, Engert F, Macklin JJ, Filosa A, Aggarwal A, Kerr RA, Takagi R, Kracun S, Shigetomi E, Khakh BS, Baier H, Lagnado L, Wang SS, Bargmann CI, Kimmel BE, Jayaraman V, Svoboda K, Kim DS, Schreiter ER, Looger LL, Optimization of a GCaMP calcium indicator for neural activity imaging. The Journal of neuroscience : the official journal of the Society for Neuroscience 32, 13819-13840 (2012). [PubMed: 23035093]

37. Sala F, Hernandez-Cruz A, Calcium diffusion modeling in a spherical neuron. Relevance of buffering properties. Biophys J 57, 313-324 (1990). [PubMed: 2317553]

38. Hansen AJ, Effect of anoxia on ion distribution in the brain. Physiol Rev 65, 101-148 (1985). [PubMed: 3880896]

39. Evans SJ, Jones JV, Levi AJ, Reduction in external K causes increased action potential shortening in ventricular myocytes from the spontaneously hypertensive rat. J Hypertens 15, 659-666 (1997). [PubMed: 9218186]

40. Bay V, Butt AM, Relationship between glial potassium regulation and axon excitability: a role for glial Kir4.1 channels. Glia 60, 651-660 (2012). [PubMed: 22290828] 
41. Davis PW, Vincenzi FF, Ca-ATPase activation and NaK-ATPase inhibition as a function of calcium concentration in human red cell membranes. Life sciences. Pt. 2: Biochemistry, general and molecular biology 10, 401-406 (1971).

42. Konishi M, Olson A, Hollingworth S, Baylor SM, Myoplasmic binding of fura-2 investigated by steady-state fluorescence and absorbance measurements. Biophys J 54, 1089-1104 (1988).

[PubMed: 3266079]

43. Blatter LA, Wier WG, Intracellular diffusion, binding, and compartmentalization of the fluorescent calcium indicators indo-1 and fura-2. Biophys J 58, 1491-1499 (1990). [PubMed: 2275965]

44. Xie Z, Molecular mechanisms of Na/K-ATPase-mediated signal transduction. Ann N Y Acad Sci 986, 497-503 (2003). [PubMed: 12763870]

45. Liang M, Cai T, Tian J, Qu W, Xie ZJ, Functional characterization of Src-interacting Na/K-ATPase using RNA interference assay. J Biol Chem 281, 19709-19719 (2006). [PubMed: 16698801]

46. Powis DA, Wattus GD, The stimulatory effect of calcium on Na, K-ATPase of nervous tissue. FEBS Lett 126, 285-288 (1981). [PubMed: 6263700]

47. Chiancone E, Thulin E, Boffi A, Forsen S, Brunori M, Evidence for the interaction between the calcium indicator 1,2-bis(o-aminophenoxy)ethane-N,N,N',N'-tetraacetic acid and calcium-binding proteins. J Biol Chem 261, 16306-16308 (1986). [PubMed: 3097007]

48. Steck TL, Kant JA, Preparation of impermeable ghosts and inside-out vesicles from human erythrocyte membranes. Methods Enzymol 31, 172-180 (1974). [PubMed: 4370662]

49. Lancaster B, Batchelor AM, Novel action of BAPTA series chelators on intrinsic K+ currents in rat hippocampal neurones. J Physiol 522 Pt 2, 231-246 (2000). [PubMed: 10639100]

50. Tsien RY, A non-disruptive technique for loading calcium buffers and indicators into cells. Nature 290, 527-528 (1981). [PubMed: 7219539]

51. Jacob SW, de la Torre JC, Pharmacology of dimethyl sulfoxide in cardiac and CNS damage. Pharmacol Rep 61, 225-235 (2009). [PubMed: 19443933]

52. Miyawaki A, Llopis J, Heim R, McCaffery JM, Adams JA, Ikura M, Tsien RY, Fluorescent indicators for $\mathrm{Ca} 2+$ based on green fluorescent proteins and calmodulin. Nature 388, 882-887 (1997). [PubMed: 9278050]

53. Mank M, Griesbeck O, Genetically encoded calcium indicators. Chem Rev 108, 15501564 (2008).

54. Nakai J, Ohkura M, Imoto K, A high signal-to-noise $\mathrm{Ca}(2+)$ probe composed of a single green fluorescent protein. Nat Biotechnol 19, 137-141 (2001). [PubMed: 11175727]

55. Rose EM, Koo JC, Antflick JE, Ahmed SM, Angers S, Hampson DR, Glutamate transporter coupling to Na,K-ATPase. The Journal of neuroscience : the official journal of the Society for Neuroscience 29, 8143-8155 (2009). [PubMed: 19553454]

56. Honegger $\mathrm{P}$, Pardo B, Separate neuronal and glial $\mathrm{Na}+\mathrm{K}+$-ATPase isoforms regulate glucose utilization in response to membrane depolarization and elevated extracellular potassium. J Cereb Blood Flow Metab 19, 1051-1059 (1999). [PubMed: 10478657]

57. Belusa R, Aizman O, Andersson RM, Aperia A, Changes in $\mathrm{Na}(+)-\mathrm{K}(+)$-ATPase activity influence cell attachment to fibronectin. Am J Physiol Cell Physiol 282, C302-309 (2002). [PubMed: 11788341]

58. Reich CG, Mason SE, Alger BE, Novel form of LTD induced by transient, partial inhibition of the Na,K-pump in rat hippocampal CA1 cells. J Neurophysiol 91, 239-247 (2004). [PubMed: 14715719]

59. James PF, Grupp IL, Grupp G, Woo AL, Askew GR, Croyle ML, Walsh RA, Lingrel JB, Identification of a specific role for the Na,K-ATPase alpha 2 isoform as a regulator of calcium in the heart. Mol Cell 3, 555-563 (1999). [PubMed: 10360172]

60. Sandercock DA, Mitchell MA, The role of sodium ions in the pathogenesis of skeletal muscle damage in broiler chickens. Poult Sci 83, 701-706 (2004). [PubMed: 15109070]

61. Dostanic-Larson I, Lorenz JN, Van Huysse JW, Neumann JC, Moseley AE, Lingrel JB, Physiological role of the alpha1- and alpha2-isoforms of the Na+-K+-ATPase and biological significance of their cardiac glycoside binding site. Am J Physiol Regul Integr Comp Physiol 290, R524-528 (2006). [PubMed: 16467499] 
62. Lin JH, Weigel H, Cotrina ML, Liu S, Bueno E, Hansen AJ, Hansen TW, Goldman S, Nedergaard M, Gap-junction-mediated propagation and amplification of cell injury. Nat Neurosci 1, 494-500 (1998). [PubMed: 10196547]

63. Brewer GJ, Torricelli JR, Isolation and culture of adult neurons and neurospheres. Nat Protoc 2, 1490-1498 (2007). [PubMed: 17545985]

64. Roy NS, Chandler-Militello D, Lu G, Wang S, Goldman SA, Retrovirally mediated telomerase immortalization of neural progenitor cells. Nat Protoc 2, 2815-2825 (2007). [PubMed: 18007617]

65. Keyoung HM, Roy NS, Benraiss A, Louissaint A, Jr., Suzuki A, Hashimoto M, Rashbaum WK, Okano H, Goldman SA, High-yield selection and extraction of two promoter-defined phenotypes of neural stem cells from the fetal human brain. Nature biotechnology 19, 843-850 (2001).

66. Windrem MS, Schanz SJ, Guo M, Tian GF, Washco V, Stanwood N, Rasband M, Roy NS, Nedergaard M, Havton LA, Wang S, Goldman SA, Neonatal chimerization with human glial progenitor cells can both remyelinate and rescue the otherwise lethally hypomyelinated shiverer mouse. Cell stem cell 2, 553-565 (2008). [PubMed: 18522848]

67. Sreejit P, Kumar S, Verma RS, An improved protocol for primary culture of cardiomyocyte from neonatal mice. In Vitro Cell Dev Biol Anim 44, 45-50 (2008). [PubMed: 18297366]

68. Benraiss A, Chmielnicki E, Lerner K, Roh D, Goldman SA, Adenoviral brain-derived neurotrophic factor induces both neostriatal and olfactory neuronal recruitment from endogenous progenitor cells in the adult forebrain. The Journal of neuroscience : the official journal of the Society for Neuroscience 21, 6718-6731 (2001). [PubMed: 11517261]

69. Brookes N, Yarowsky PJ, Determinants of deoxyglucose uptake in cultured astrocytes: the role of the sodium pump. J Neurochem 44, 473-479 (1985). [PubMed: 2578179]

70. Ridderstap AS, Bonting SL, Na+-K+-activated ATPase and exocrine pancreatic secretion in vitro. The American journal of physiology 217, 1721-1727 (1969). [PubMed: 4242846]

71. Erdmann E, Krawietz W, Phillipp G, Hackbarth I, Schmitz W, Scholz H, Stimulatory effect of vanadate on $(\mathrm{Na}++\mathrm{K}+)$-ATPase activity and on $3 \mathrm{H}$-ouabain-binding in a cat heart cell membrane preparation. Nature 278, 459-461 (1979). [PubMed: 221820]

72. Beauge LA, Glynn IM, Commercial ATP containing traces of vanadate alters the response of (Na+ + K+) ATPase to external potassium. Nature 272, 551-552 (1978). [PubMed: 211418]

73. Zuba-Surma EK, Kucia M, Abdel-Latif A, Lillard JW, Jr., Ratajczak MZ, The ImageStream System: a key step to a new era in imaging. Folia Histochem Cytobiol 45, 279-290 (2007). [PubMed: 18165167]

74. Tian GF, Azmi H, Takano T, Xu Q, Peng W, Lin J, Oberheim N, Lou N, Wang X, Zielke HR, Kang J, Nedergaard M, An astrocytic basis of epilepsy. Nat Med 11, 973981 (2005).

75. Schulz K, Sydekum E, Krueppel R, Engelbrecht CJ, Schlegel F, Schroter A, Rudin M, Helmchen F, Simultaneous BOLD fMRI and fiber-optic calcium recording in rat neocortex. Nat Methods 9, 597-602 (2012). [PubMed: 22561989]

76. Thrane AS, Rappold PM, Fujita T, Torres A, Bekar LK, Takano T, Peng W, Wang F, Rangroo Thrane V, Enger R, Haj-Yasein NN, Skare O, Holen T, Klungland A, Ottersen OP, Nedergaard M, Nagelhus EA, Critical role of aquaporin-4 (AQP4) in astrocytic Ca2+ signaling events elicited by cerebral edema. Proc Natl Acad Sci U S A 108, 846-851 (2011). [PubMed: 21187412]

77. Ding S, Fellin T, Zhu Y, Lee SY, Auberson YP, Meaney DF, Coulter DA, Carmignoto G, Haydon $\mathrm{PG}$, Enhanced astrocytic $\mathrm{Ca} 2+$ signals contribute to neuronal excitotoxicity after status epilepticus. The Journal of neuroscience : the official journal of the Society for Neuroscience 27, 10674-10684 (2007). [PubMed: 17913901]

78. Nedergaard M, Hansen AJ, Characterization of cortical depolarizations evoked in focal cerebral ischemia. J Cereb Blood Flow Metab 13, 568-574 (1993). [PubMed: 8314912] 


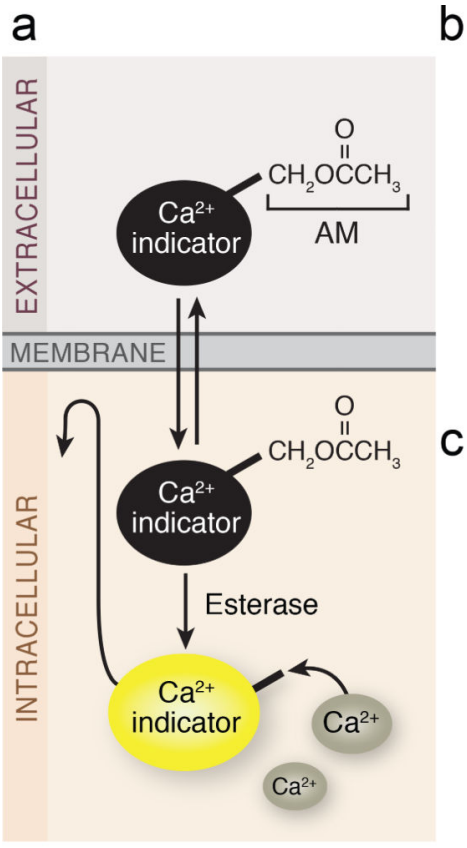

b
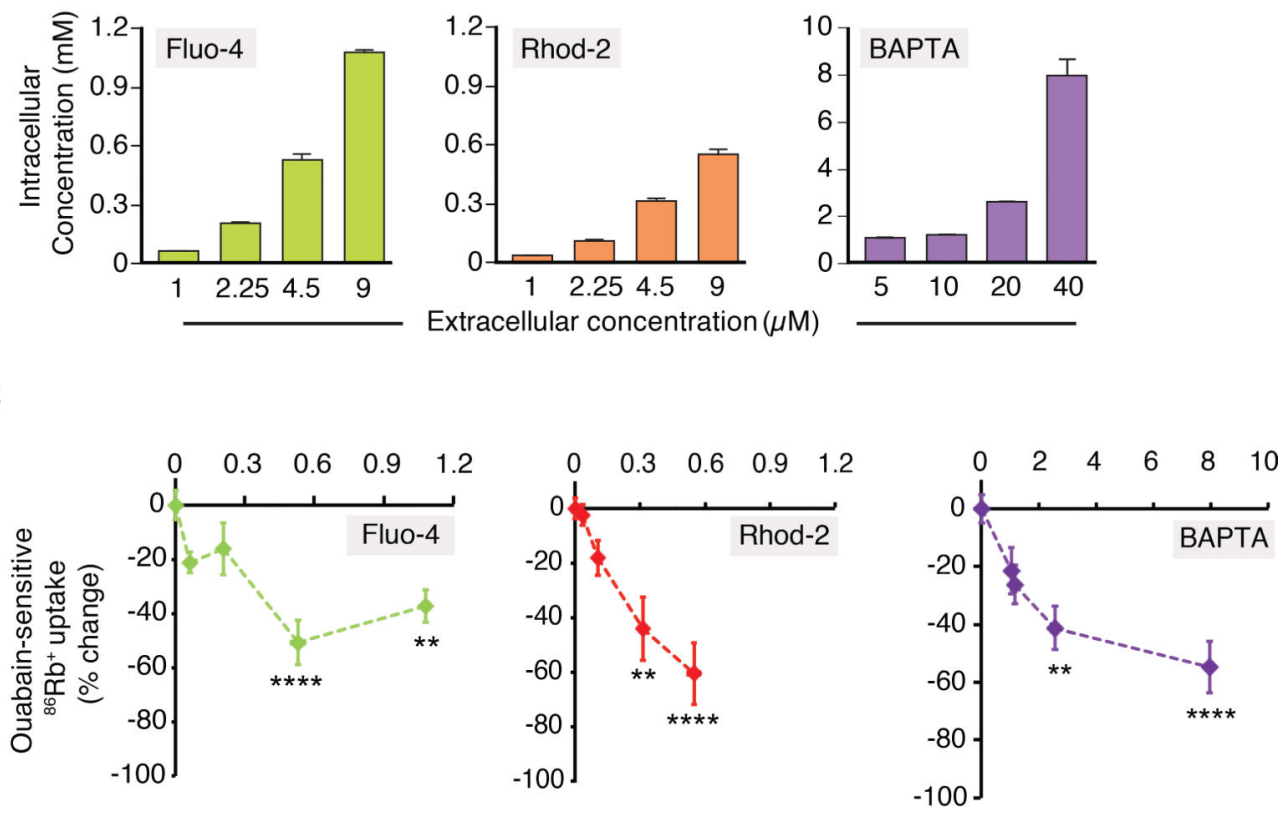

Intracellular concentration (mM)

$-100$

Fig. 1. Suppression of ouabain-sensitive ${ }^{86} \mathrm{Rb}^{+}$uptake by $\mathrm{Ca}^{2+}$ indicators in cultured mouse astrocytes.

(a) Acetoxymethyl (AM) ester derivatives of $\mathrm{Ca}^{2+}$ indicators $\left(\mathrm{Ca}^{2+}\right.$ insensitive and nonfluorescence), which across cell membranes non-invasively, are cleaved by esterases in the cells. The ionized active form of $\mathrm{Ca}^{2+}$ indicators $\left(\mathrm{Ca}^{2+}\right.$ sensitive $)$ remains trapped within the cells. (b) Intracellular Fluo-4, Rhod-2, and BAPTA concentrations after the loading of various concentrations of $A M$ indicators ( $n=4$ wells). (c) The ouabain $(1 \mathrm{mM})$-sensitive ${ }^{86} \mathrm{Rb}$ + uptake without or with pre-incubation of Fluo-4 AM (1-9 $\mu \mathrm{M})$, Rhod-2 AM (1-9 $\mu \mathrm{M})$ or BAPTA AM $(5-40 \mu \mathrm{M})$. The data were expressed as percent change from control and plotted against intracellular concentrations ( $\mathrm{n}=4-6$ wells). $* * \mathrm{p}<0.01, * * * * \mathrm{p}<0.0001$ compared to vehicle control (0.2\% DMSO). Displayed are means \pm S.E.M. 


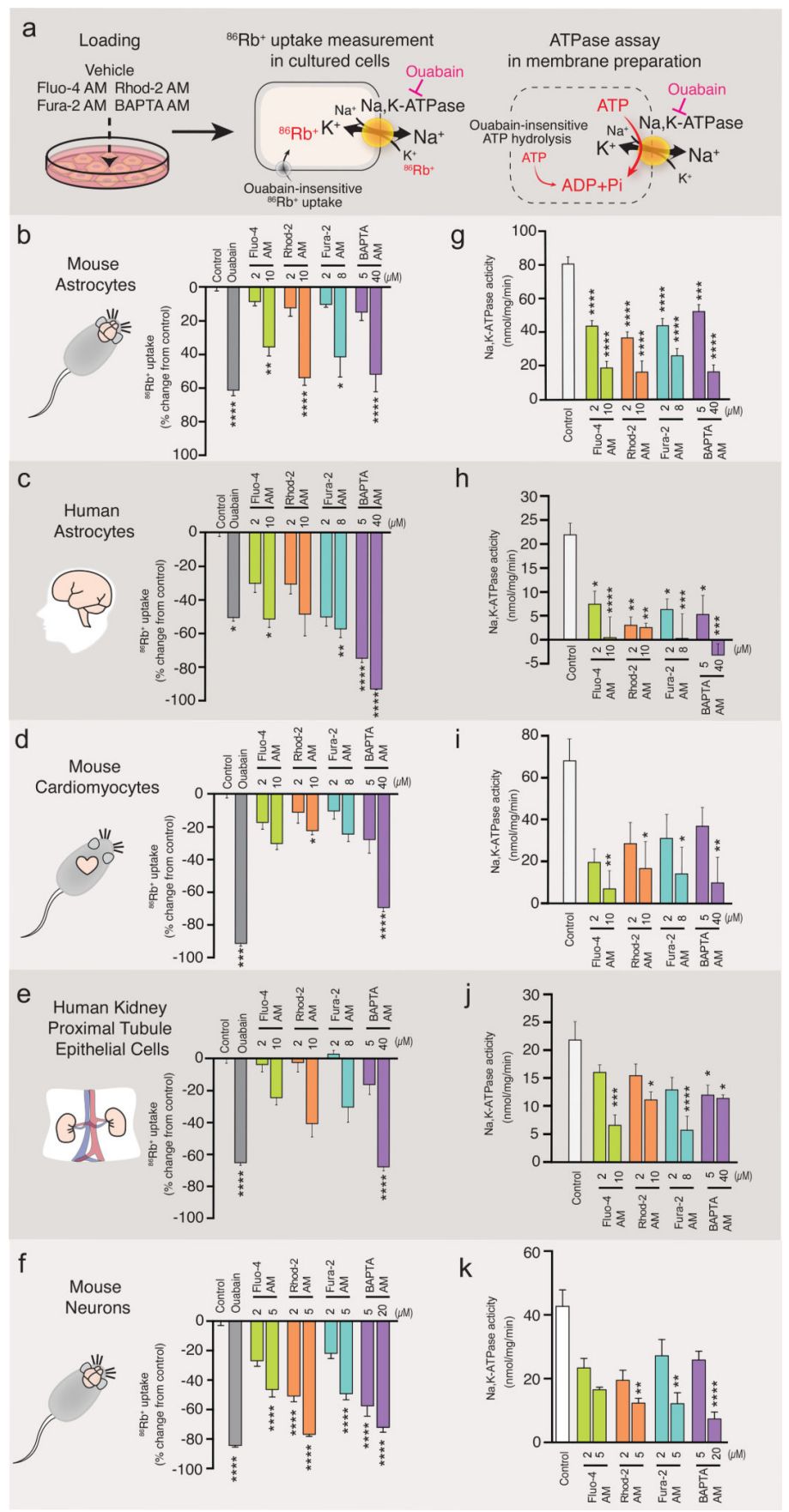

Fig. 2. $\mathrm{Ca}^{2+}$ indicators inhibited $\mathrm{Na}, \mathrm{K}-\mathrm{ATPase}$ in 4 different types of cultured cells.

(a) Schematic diagram outlining the measurement of ${ }^{86} \mathrm{Rb}^{+}$uptake by cells and $\mathrm{Na}, \mathrm{K}$ ATPase activity in membrane preparation. (b-i) $\mathrm{Ca}^{2+}$ indicators (Fluo-4 AM, Rhod-2 AM and Fura-2 AM) or BAPTA AM were preloaded for $30 \mathrm{~min}$ in cultured mouse astrocytes (b,c; $\mathrm{n}=8-27$ wells), human astrocytes $(\mathbf{d}, \mathbf{e} ; \mathrm{n}=5-12$ wells), mouse cardiomyocytes (f, $\mathbf{g}$; $\mathrm{n}=6-12)$, human proximal tubule epithelial cells (h,I; $\mathrm{n}=5-12$ wells), or mouse neurons (j,k; $\mathrm{n}=5$ wells) and then, ${ }^{86} \mathrm{Rb}^{+}$uptake $(\mathbf{b}, \mathbf{d}, \mathbf{f}, \mathbf{h}, \mathbf{j})$ or $\mathrm{Na}, \mathrm{K}$-ATPase activity $(\mathbf{c}, \mathbf{e}, \mathbf{g}, \mathbf{I}, \mathbf{k})$ was measured. Ouabain $(1 \mathrm{mM})$ was used to distinguish $\mathrm{Na}, \mathrm{K}$-ATPase-mediated ${ }^{86} \mathrm{Rb}^{+}$uptake or 
ATP hydrolysis. ${ }^{*} \mathrm{p}<0.05,{ }^{*} \mathrm{p}<0.01, * * * \mathrm{p}<0.001, * * * * \mathrm{p}<0.0001$ compared to vehicle control (0.2\% DMSO). Displayed are means \pm S.E.M. 


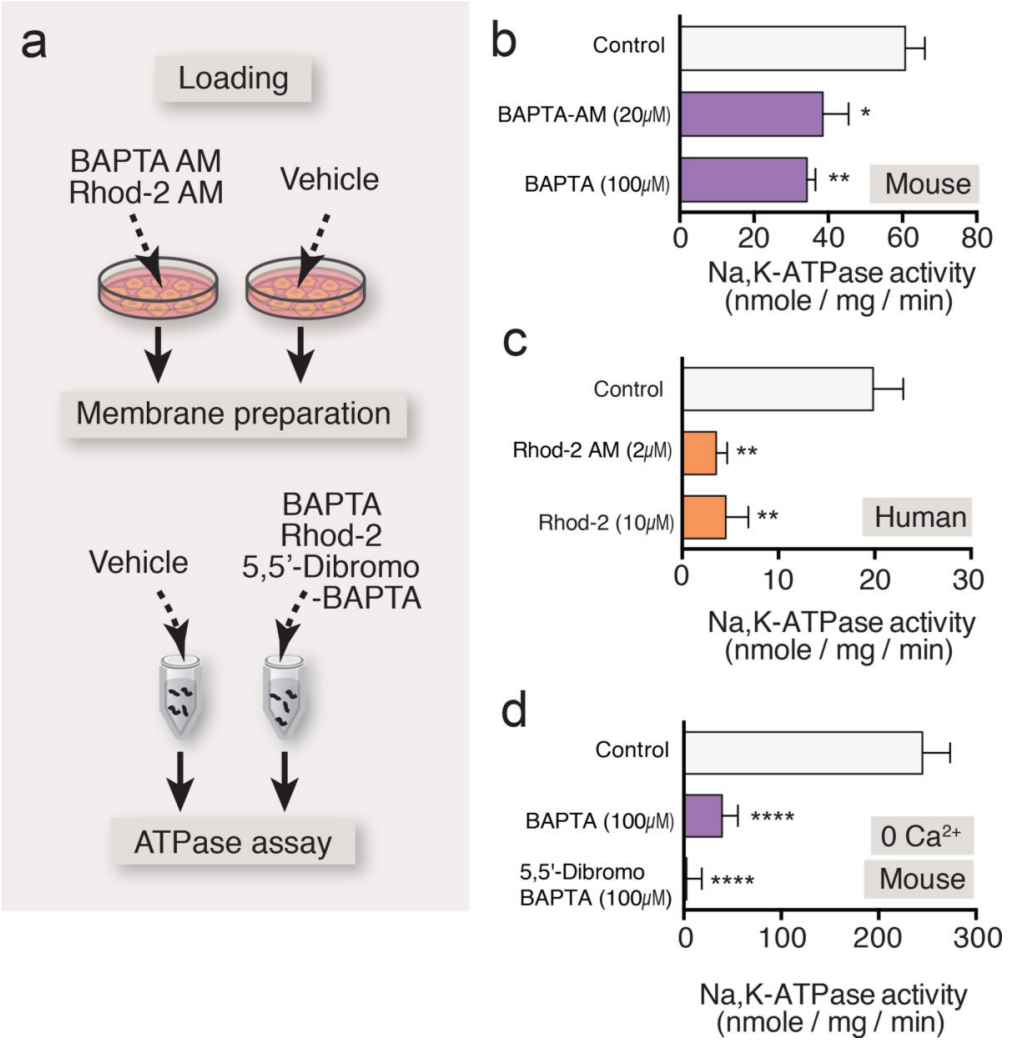

Fig. 3. $\mathrm{Ca}^{2+}$ indicators directly inhibited Na,K-ATPase and diminished the GPCR-mediated enhancement of $\mathrm{K}^{+}$uptake.

(a) Schematic diagram outlining the ATPase assay with AM and salt form of BAPTA or Rhod-2 in membrane preparation. (b) Addition of BAPTA tetrapotassium salt $(100 \mu \mathrm{M})$ to membrane preparation induced significant inhibition of Na,K-ATPase activity, which was comparable to that induced by preincubation of BAPTA AM $(20 \mu \mathrm{M})$ in cultured mouse astrocytes ( $n=8-14$ wells). (c) Effect of Rhod-2 tripotassium salt $(10 \mu \mathrm{M})$ on ouabainsensitive ATP hydrolysis in membrane preparation compared to the preincubation of Rhod-2 AM ( $2 \mu \mathrm{M})$ in cultured human astrocyte ( $\mathrm{n}=8$ wells). (d) Na,K-ATPase activity measurement in the absence or presence of BAPTA tetrapotassium salt $(100 \mu \mathrm{M})$ or low $\mathrm{Ca}^{2+}$ affinity 5,5'-dibromo BAPTA tetrapotassium salt $(100 \mu \mathrm{M})$ in the zero $\mathrm{Ca}^{2+}$ assay buffer in cultured mouse astrocytes ( $\mathrm{n}=8-14$ wells). $* \mathrm{p}<0.05, * * \mathrm{p}<0.01, * * * * \mathrm{p}<0.0001$ compared to vehicle control (b and d, 0.1\% DMSO; c, 0.04\% DMSO). Displayed are means \pm S.E.M. 
a

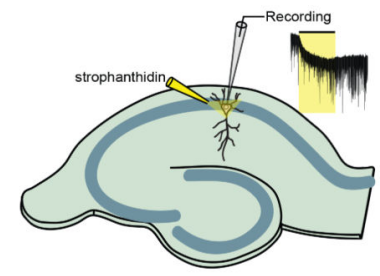

d

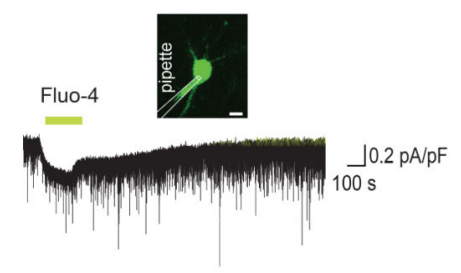

g

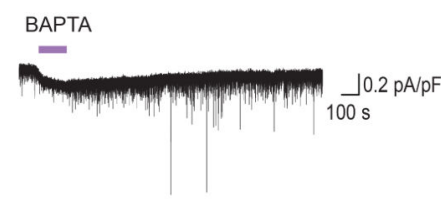

b

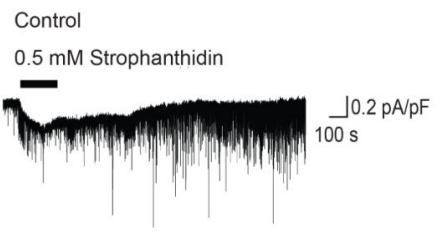

e

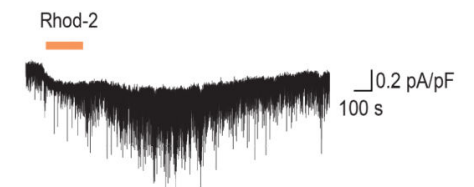

$\mathrm{h}$
C

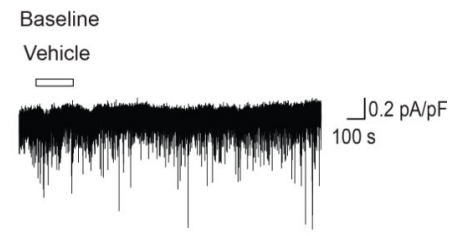

f

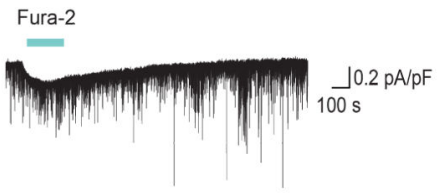

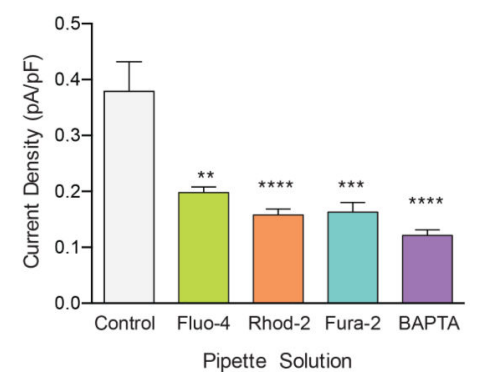

Fig. 4. $\mathrm{Ca}^{2+}$ indicators inhibited $\mathrm{Na}, \mathrm{K}$-ATPase current in pyramidal neurons of hippocampal CA1 region.

(a) Schematic diagram outlining the measurement of ${ }^{86} \mathrm{Rb}^{+}$uptake by cells and $\mathrm{Na}, \mathrm{K}$ ATPase activity in membrane preparation. (b) $\mathrm{Na}, \mathrm{K}$-ATPase current was measured by the application of $0.5 \mathrm{mM}$ strophanthidin for $2 \mathrm{~min}$. (c) Baseline recording of the holding current using vehicle without strophanthidin. (d-g) Membrane-impermeable $\mathrm{Ca}^{2+}$ indicators (Fluo-4, Rhod-2, and Fura-2) or membrane-impermeable BAPTA was included in the recording pipette to measure their effect on Na,K-ATPase current. 10 minutes after breaking into the neuron, cells were found to be loaded with the $\mathrm{Ca}^{2+}$ indicator (inset of panel $\mathbf{d}$; scale

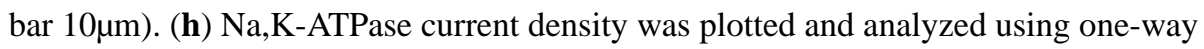
ANOVA (Control, $0.34 \pm 0.05 \mathrm{pA} / \mathrm{pF}$; Fluo-4, $0.20 \pm 0.01 \mathrm{pA} / \mathrm{pF}$; Rhod-2, $0.16 \pm 0.01$ $\mathrm{pA} / \mathrm{pF}$; Fura-2, $0.16 \pm 0.02 \mathrm{pA} / \mathrm{pF}$; BAPTA, $0.12 \pm 0.01 \mathrm{pA} / \mathrm{pF}$ ( $\mathrm{n}=4-5$ mice; **p $<0.01$, $* * * \mathrm{p}<0.001, * * * * \mathrm{p}<0.0001$; displayed are means \pm S.E.M). 
a
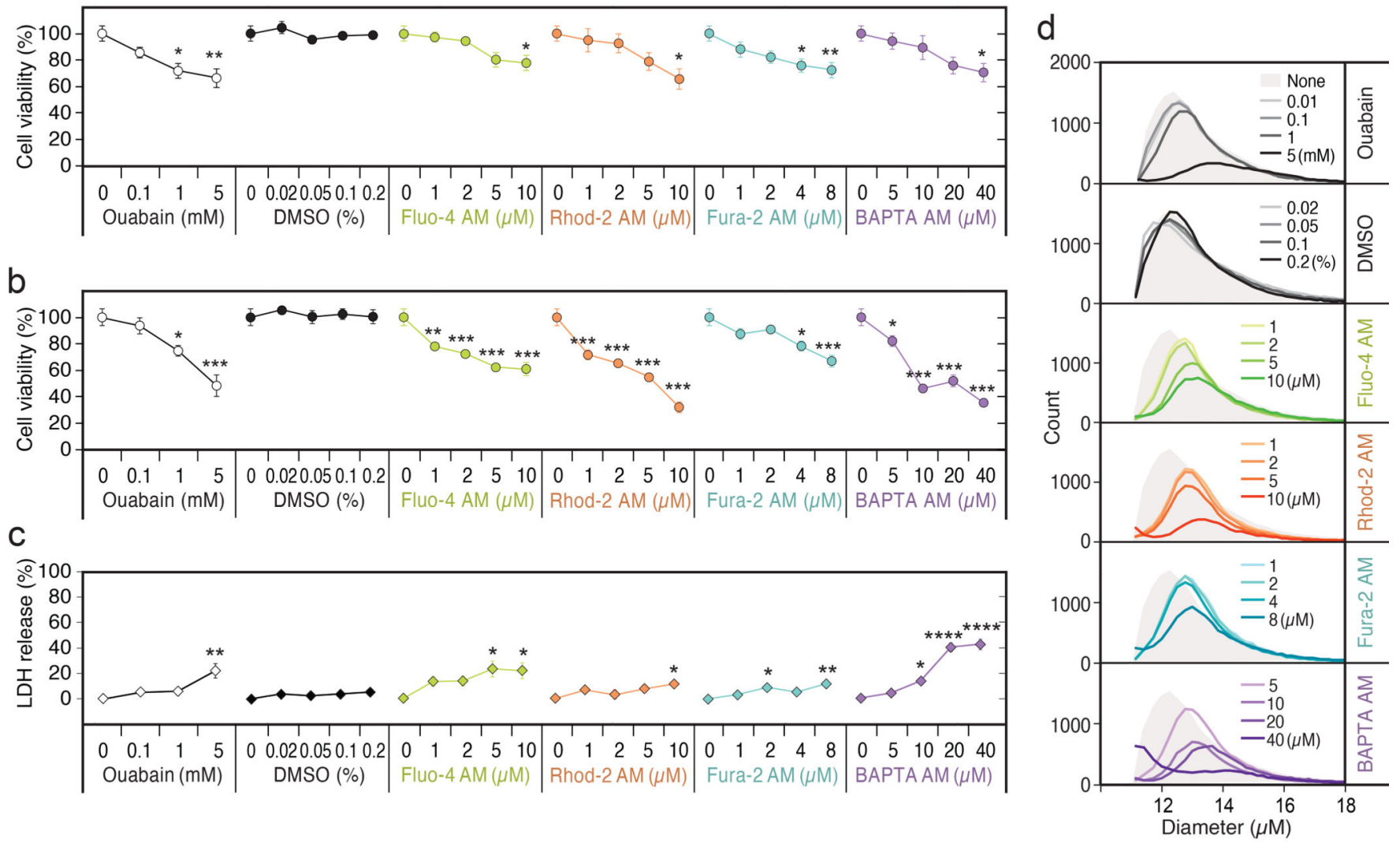

b

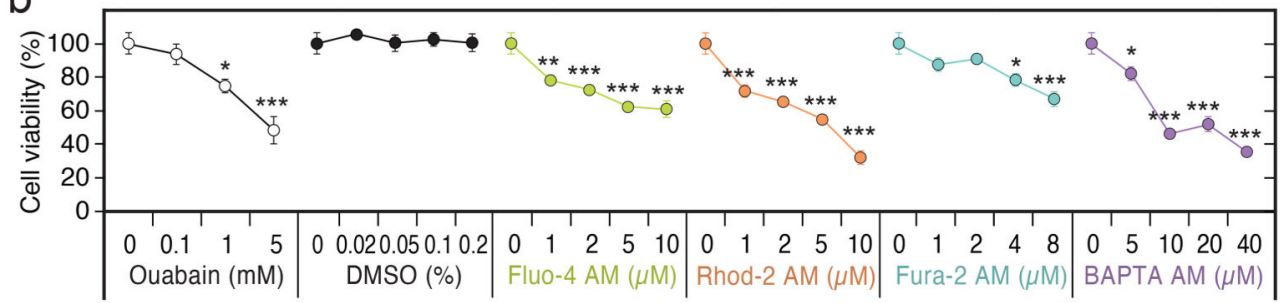

C

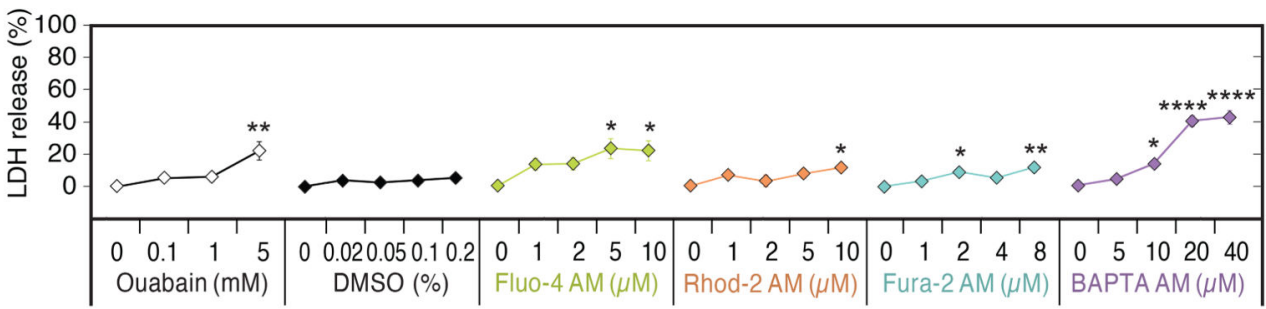

e

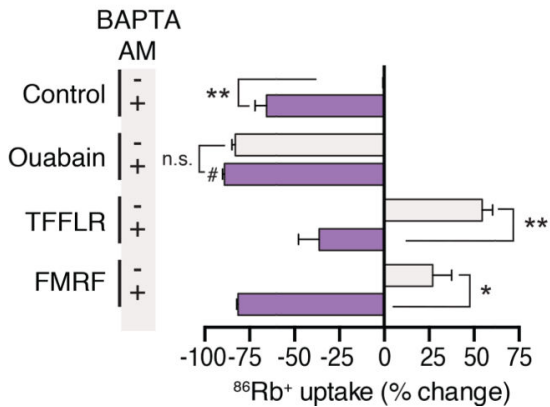

f

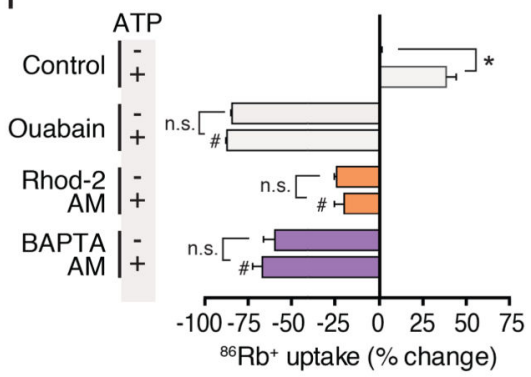

Fig. 5. $\mathrm{Ca}^{2+}$ indicators induced swelling and cell death of mouse astrocytes.

(a) Assessment of the viable cell number by counting. Cultured mouse astrocytes were treated with increasing concentrations of ouabain (0-5 mM), DMSO (0-0.2\%), $\mathrm{Ca}^{2+}$ indicators (1-10 $\mu \mathrm{M}$ in $0.2 \%$ DMSO) and BAPTA AM (5-40 $\mu \mathrm{M}$ in 0.2\% DMSO) for 30 min, and the cell viability was examined at $24 \mathrm{~h}$ ( $\mathrm{n}=8$ wells). ${ }^{*} \mathrm{p}<0.05,{ }^{* *} \mathrm{p}<0.01$ compared to no treatment control. (b) When the loading time was extended to $2 \mathrm{~h}$, further loss of viability was observed at $24 \mathrm{~h}$ for the lower concentrations ( $\mathrm{n}=5-6$ wells). ${ }^{*} \mathrm{p}<0.05,{ }^{* * *} \mathrm{p}<0.001$ compared to no treatment control. (c) LDH release was examined immediately after $2 \mathrm{~h}$ treatment with the indicators $(\mathrm{n}=6) . * \mathrm{p}<0.05, * * \mathrm{p}<0.001, * * * * \mathrm{p}<0.0001$ compared to no treatment control. (d) Relative increases in diameter of viable cells at $24 \mathrm{~h}$ induced by treatment of various concentrations of ouabain, DMSO, $\mathrm{Ca}^{2+}$ indicators and BAPTA AM for $2 \mathrm{~h}$ in cultured mouse astrocytes ( $\mathrm{n}=4$ wells). (e) Loading of BAPTA AM $(20 \mu \mathrm{M})$ abolished the TFLLR-NH $2(30 \mu \mathrm{M})$ - and FMRF $\left(15 \mu \mathrm{M}\right.$ in MrgA1 ${ }^{+/-}$culture $)$mediated enhancement 
of ${ }^{86} \mathrm{Rb}^{+}$uptake by cultured mouse astrocytes ( $\mathrm{n}=4-38$ wells). n.s., $* * * * \mathrm{p}<0.0001$ compared to (-) BAPTA AM of control group $(0.1 \%$ DMSO). (f) ATP $(100 \mu \mathrm{M})$ mediated increase in ${ }^{86} \mathrm{Rb}^{+}$uptake was suppressed by preloading of Rhod-2 AM $(4.5 \mu \mathrm{M})$ and BAPTA AM (20 $\mu \mathrm{M})$ in cultured mouse astrocytes $\left(\mathrm{n}=4-38\right.$ wells). n.s., ${ }^{*} \mathrm{p}<0.05$ compared to (-) ATP of each group, ${ }^{\#} \mathrm{p}<0.05$ compared to (+) ATP of control group (0.1\% DMSO). Displayed are means \pm S.E.M. 

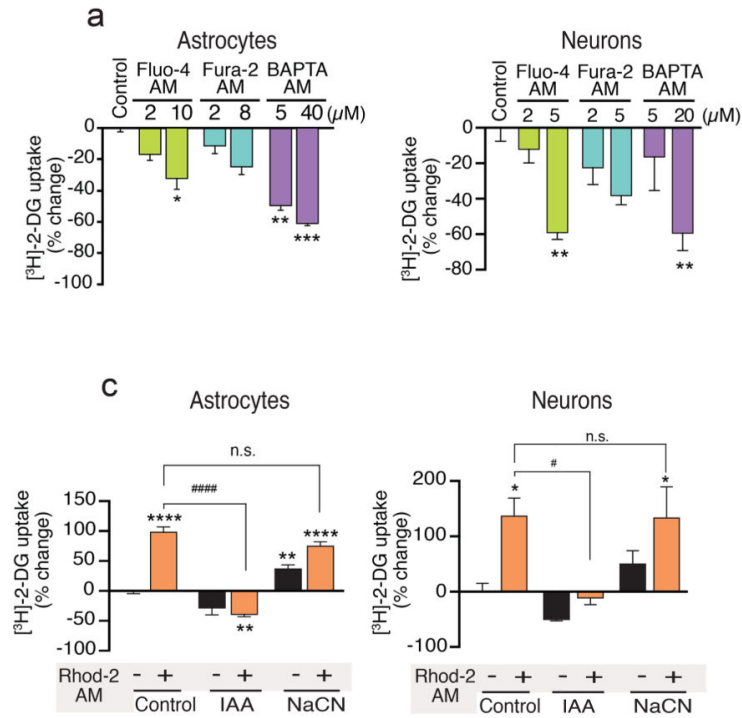
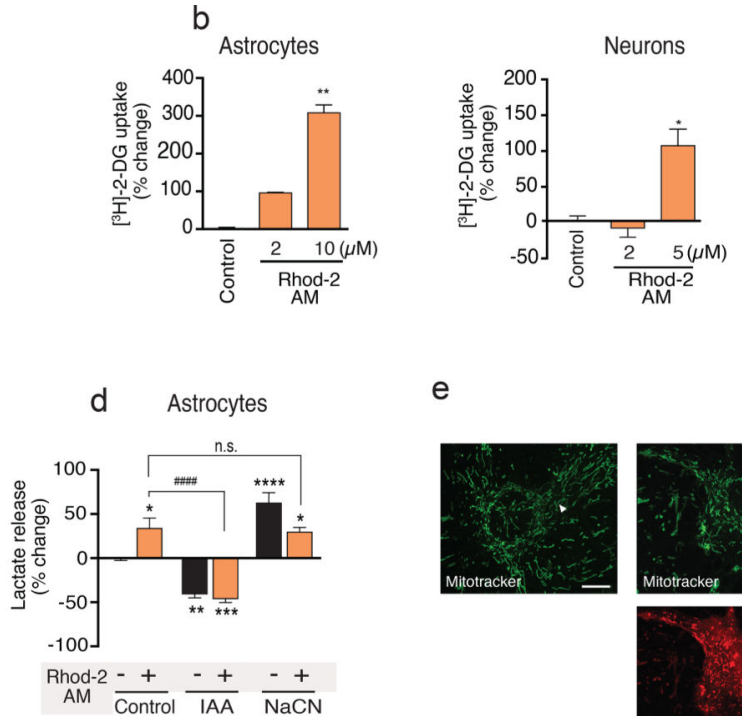

e
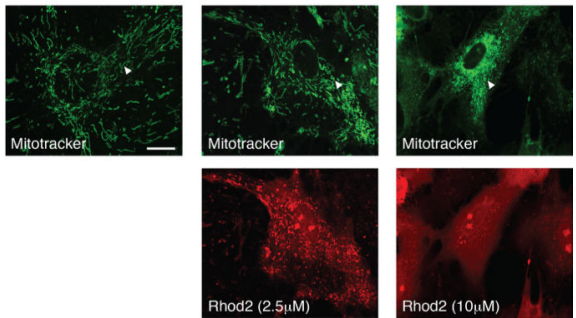

Fig. 6. $\mathrm{Ca}^{2+}$ indicators altered glucose uptake and lactate release of cultured mouse astrocytes and neurons.

(a) $\left[{ }^{3} \mathrm{H}\right]$-2-deoxyglucose $\left(\left[{ }^{3} \mathrm{H}\right]-2-\mathrm{DG}\right)$ uptake was inhibited by loading of Fluo-4 AM,

Fura-2 AM and BAPTA AM in mouse astrocyte cultures and neuronal cultures $(n=4-12$ wells). (b) Enhancement of $\left[{ }^{3} \mathrm{H}\right]-2-D G$ uptake induced by Rhod-2 AM in mouse astrocyte and neuronal cultures. $\left[{ }^{3} \mathrm{H}\right]-2-\mathrm{DG}$ uptake was examined with Rhod-2 AM loaded cells ( $\mathrm{n}=4-$ 8 wells). $* * * \mathrm{p}<0.001, * * * * \mathrm{p}<0.0001$ compared to vehicle control $(0.2 \%$ DMSO, a and b).

(c) Effects of metabolic inhibition on $\left[{ }^{3} \mathrm{H}\right]-2-\mathrm{DG}$ uptake in cultured mouse astrocytes and neurons. Inhibition of mitochondrial oxidative metabolism by sodium cyanide ( $\mathrm{NaCN}, 100$ $\mu \mathrm{M}, \mathrm{n}=8$ ) enhanced $\left[{ }^{3} \mathrm{H}\right]-2-\mathrm{DG}$ uptake. Application of a glycolysis inhibitor, iodoacetate (IAA, $300 \mu \mathrm{M})$, decreased $\left[{ }^{3} \mathrm{H}\right]-2-D G$ uptake and inhibited the Rhod-2 AM $(2 \mu \mathrm{M})$-induced increase in $\left[{ }^{3} \mathrm{H}\right]-2-\mathrm{DG}$ uptake ( $\mathrm{n}=8-16$ wells). (d) Rhod-2 AM increased lactate release from astrocytes. Inhibition of mitochondrial oxidative metabolism by Rhod-2 AM ( $2 \mu \mathrm{M})$ and sodium cyanide $(\mathrm{NaCN}, 100 \mu \mathrm{M})$ enhanced lactate release, while application of IAA (300 $\mu \mathrm{M})$ decreased lactate release and abolished the effect of Rhod-2 AM in cultured mouse astrocytes ( $\mathrm{n}=4-8$ wells). ${ }^{*} \mathrm{p}<0.05, * * \mathrm{p}<0.01, * * * * \mathrm{p}<0.001$ compared to vehicle control

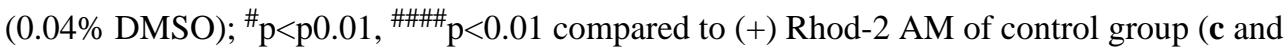
d). (e) Images of astrocytes loaded with MitoTracker (20nM),( Top Panel) and Rhod-2 AM $(2 \mu \mathrm{M}$ and $10 \mu \mathrm{M})$.(Lower panel) Scale bar, $20 \mu \mathrm{m}$. White arrows correspond to mitochondrial morphological changes. Displayed are means \pm S.E.M. 
a

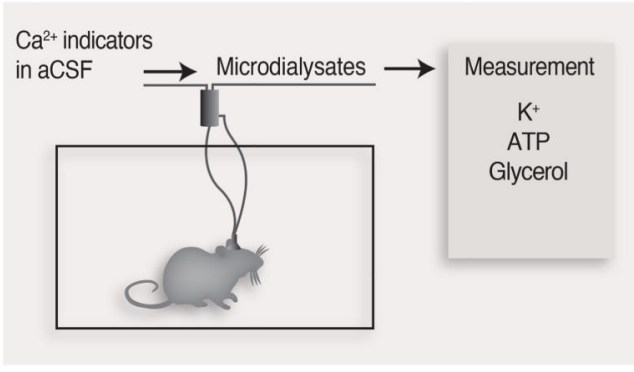

d
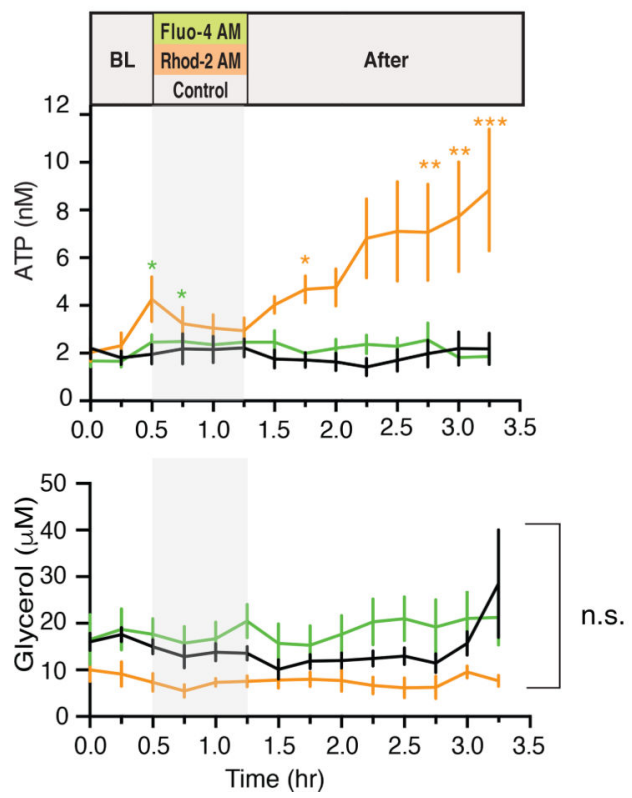

b

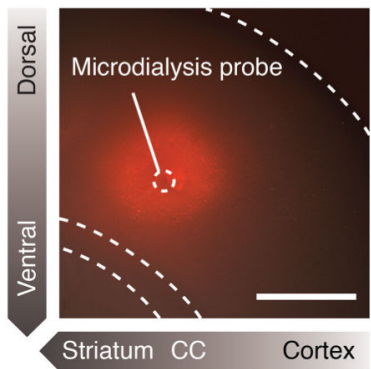

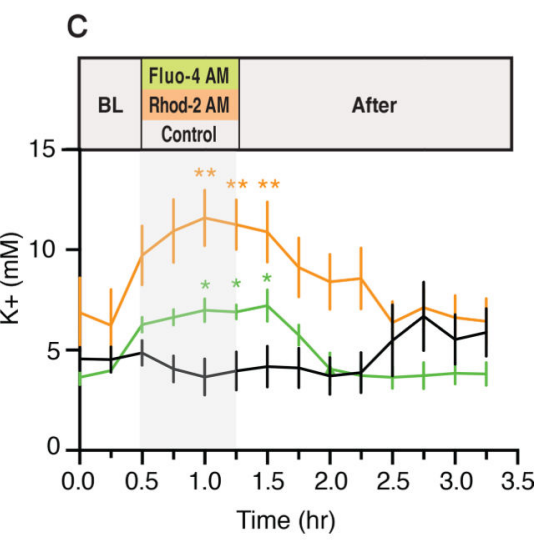

Fig. 7. $\mathrm{Ca}^{2+}$ indicator disrupts astrocyte $\mathrm{K}^{+}$uptake and tissue environments in vivo.

(a) Schematic diagram outlining the application of $\mathrm{Ca}^{2+}$ indicator and sample collection via microdialysis in freely moving mice. After overnight probe equilibration, samples were collected every 15 min before, during and after infusion of aCSF containing Fluo-4 AM, Rhod-2 AM or vehicle. (b) Image of acutely prepared coronal brain section confirming the delivery of Rhod-2 AM into tissue. Dashed circle indicates position of microdialysis probe. Scale bar, $500 \mu \mathrm{m}$. (c) Comparison of extracellular $\mathrm{K}^{+}$measurements with Fluo-4 AM, Rhod-2 AM, or control application in vivo. ( $\mathrm{n}=6-8$ mice; * $\mathrm{p}<0.05$, ** $\mathrm{p}<0.01$ compared to control group). (d) Comparison of ATP and glycerol measurements with Fluo-4 AM,

Rhod-2 AM, or control application in vivo $\left(\mathrm{n}=6-8\right.$ mice; $\mathrm{n} . \mathrm{s}$., ${ }^{*} \mathrm{p}<0.05$, ${ }^{*} \mathrm{p}<0.01$ compared to control group). Displayed are means \pm S.E.M. 
a

Rhod-2 AM

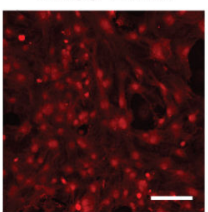

GFAP-GCaMP3

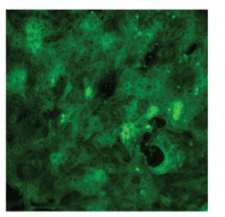

d

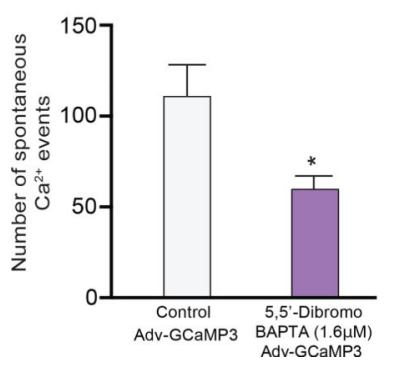

b

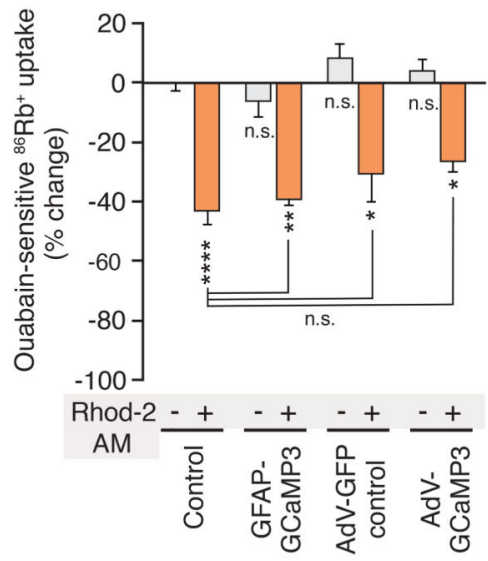

C

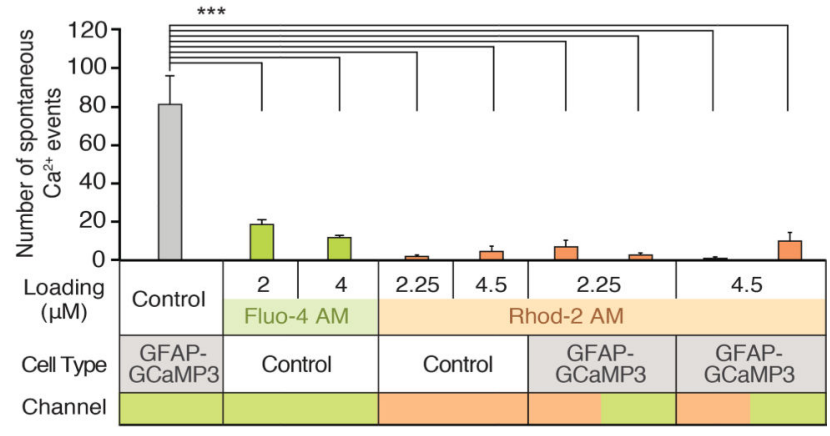

Fig. 8. Expression of GCaMP3 does not affect $\mathrm{K}^{+}$uptake of mouse astrocytes.

(a) Representative images of astrocytes loaded with Rhod-2 AM (4.5 $\mu \mathrm{M})$ or prepared from GFAPCre:GCaMP3fl transgenic mice (GFAP-GCaMP3). Scale bar, $100 \mu \mathrm{m}$. (b) GCaMP3 expression in astrocytes has no effect on Na,K-ATPase-mediated ${ }^{86} \mathrm{Rb}^{+}$uptake. GFAPGCaMP3 astrocytes showed no difference in ouabain-sensitive ${ }^{86} \mathrm{Rb}^{+}$uptake. Expression of GCaMP3 induced by adenovirus bearing Cre recombinase (100 MOI, 6 days posttransduction) in cultured astrocytes prepared from GCaMP3fl transgenic mice also had no effect on ouabain-sensitive ${ }^{86} \mathrm{Rb}^{+}$uptake (AdV-GCaMP3). Conversely, Rhod-2 AM (4 $\left.\mu \mathrm{M}\right)$ loading decreased ouabain-sensitive ${ }^{86} \mathrm{Rb}^{+}$uptake in all groups of cultured mouse astrocytes. $\mathrm{n}=6-23$ wells; *p<0.05, **p $<0.01, * * * * \mathrm{p}<0.0001$ compared to (-) Rhod-2 AM of control group (0.1\% DMSO). (c) Spontaneous $\mathrm{Ca}^{2+}$ activity in cultured mouse astrocytes. Number of spontaneous $\mathrm{Ca}^{2+}$ events were detected by Fluo-4 AM ( 2 and $\left.4 \mu \mathrm{M}\right)$, Rhod-2 AM (2.25 and $4.5 \mu \mathrm{M})$ or GCaMP3. In groups combining $\mathrm{Ca}^{2+}$ imaging of GCaMP3 with Rhod-2 AM, number of $\mathrm{Ca}^{2+}$ events detected with Rhod-2 (left, orange channel) and GCaMP3 (right, green channel) were both counted. $\mathrm{n}=4-6$ wells; ****p $<0.0001$ compared to GFAPGCaMP3 control group ( $0.1 \%$ DMSO). (d) Histogram comparing number of spontaneous $\mathrm{Ca}^{2+}$ events in Adv-GCaMP3 expressing mouse astrocytes in the presence and absence of 5,5'-Dibromo BAPTA ( $\mathrm{p}=0.4188$, unpaired t test $\mathrm{n}=4-8$ wells). Displayed are means \pm S.E.M. 